\title{
砂質地盤における超近接併設シールドトンネル の掘削に伴う地盤の緩み現象のメカニズム
}

\author{
田嶋 仁志 1 石田 高啓 2 ・斉藤 正幸 3 ・ 小林 靖典 3 ・ \\ 中西 康博 $4 \cdot$ 市川晃央 $5 \cdot$ 西村 和夫 6 \\ 1正会員 首都高速道路（株）東京建設局（干160-0023 東京都新宿区西新宿6-6-2） \\ E-mail:h.tajima118@shutoko.jp \\ 2正会員 首都高速道路（株）経営企画部（二100-8930 東京都千代田区霞が関1-4-1) \\ 3 正会員日本シビックコンサルタント（株）事業統轄本部（干116-0013 東京都荒川区西日暮里2-26-2) \\ 4正会員（株）竹中土木 東京本店技術部（广136-8570 東京都江東区新砂1-1-1） \\ 5正会員（株）竹中土木 技術本部 竹中技術研究所(干270-1395 千葉県印西市大塚1-5-1) \\ 6正会員 首都大学東京教授 都市環境学部( ₹192-0397 東京都八王子市南大沢1-1)
}

\begin{abstract}
本研究は, 併設シールドトンネルの掘削に伴う長期的な影響としての周辺地盤の緩み現象のメカニズム を明らかにするために，テールボイドの発生による「緩み厚の影響」と併設トンネルの「離隔の影響」に ついて検討を行った．2つのトンネル模型を用いたアルミ棒積層体を模擬地盤とする模型実験を実施する とともに, 個別要素法 (DEM) 解析によるシミュレーション解析を行った。 その結果, 後行トンネル掘削の 影響により先行トンネルに作用寸る土圧は増加し，2つのトンネルを跨ぐようなアーチング効果が確認で きた。 また，実施工の計測結果との比較検討も行った。
\end{abstract}

Key Words :shield tunnel, parallel tunnels, earth pressure, stress release, loosening pressure, trap door test, Distinct Element Method, stress distribution, ground deformation

\section{1. 序論}

近年, 都市部において大断面シールドトンネルの施 工が活発化しており, 輻輳する地下構造物の存在や用 地の制約などにより, 非常に近接した施工条件となっ ている，超近接シールドトンネルとしては，併設で $0.3 \mathrm{D}$ (D : トンネル外径) 以下の離隔の施工事例も少なく ない.

この様な超近接併設シールドトンネルの影響検討の 研究として, 現場計測に基づくセグメントの実挙動の

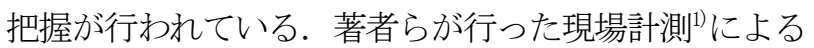
と, 後行トンネル掘削時に先行トンネルに及ぼす併設 施工の影響は, 裏込め注入圧作用時等の施工時の短期 的な影響と施工完了後の併設安定期の長期的な影響に 大別され，併設時の先行トンネルは，短期的な影響と して後行トンネルから押される方向に, 長期的な影響 として後行トンネルに引き込まれる方向に断面力が増 加した結果が示されている. 寸なわち, 併設時の先行 トンネルは，施工時は後行トンネルの裏込め注入圧等 の影響により押される挙動を示し，併設安定期は後行 トンネルを掘削することにより生じる地盤内応力の再
配分と考えられる影響により上下につぶされるような 挙動を示す. したがって, 短期的な影響は施工時の一 時的なものであり，シールドマシン通過後にはその影 響は解消傾向にあり，長期的な影響としての緩み土圧 による地盤内応力の再配分の影響が支配的となること から，短期及び長期的な影響をそれぞれ評価し，設計 に反映させることが重要である.

砂質地盤における単設のシールドトンネルの設計は, Terzaghiの緩み土圧 2) 基本に考えられている. 一方, 併 設のシールドトンネルが近接する場合, 前述の現場計 測事例の通り，先行トンネルは後行トンネルの施工に より地盤の応力再配分の影響を受けると考えられてい る. しかしながら, その現象も十分に把握されておら ず，影響評価方法を明確に記述している指針例えば3),4 は ない，一般的には，離隔が1.0D未満の近接した場合に は併設の影響を無視できず検討が必要であると言われ ているのが現状である.

緩み土圧を求める研究は, 村山 ${ }^{5}$, 村山・松岡 ${ }^{6}$ によ る円形のアルミ棒を用いた降下床実験，足立ら 直径可変型のトンネル模型を用いた模型実験, 芥川ら によるエアーバッグを用いたトンネル掘削シミュレー 


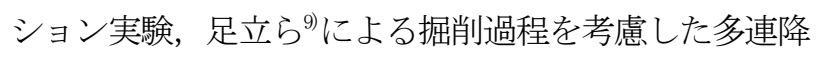
下床実験など，多くの模型実験が行われてきた．また，

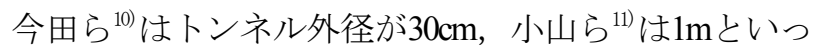
た比較的大きな模型を用いた実験を行っている.

水平に近接するトンネルの応力再配分に関する研究 は, 多連降下床実験やトンネル模型を用いた実験及び 解析により行われている. 多連降下床実験に関しては, 垂水ら ${ }^{12}$ による 2 連降下床実験, 鈴木ら ${ }^{13)}$ による5連降下 床実験, 土門ら ${ }^{14}$ による3連降下床実験などが行われて いる. トンネル模型を用いた2つの併設トンネルの緩み 実験に関しては，桜井ら ${ }^{15}$ によるエアーバッグを用いた トンネル模型による双設トンネルの同時掘削に関する 実験, 小坂ら ${ }^{16)}$ による掘進可能なトンネル模型を用いた 遠心載荷装置による実験及び個別要素法解析 (以下, DEM解析), 高野ら ${ }^{17)}$ による掘進可能な矩形卜ンネル模 型を用いた遠心載荷装置による実験などが行われてき た.これらの既往の研究において, 近接してトンネル を順次掘削する場合, 先行側は後行側の掘削により, 応力の再配分の影響を受け土圧が増加すると報告して いる.

前述の既往の研究では，土被りや離隔をパラメータ とした研究が多く, テールボイドによる緩み量の違い による緩み土圧の評価を行った研究事例は無く, 超近 接の離隔に対する研究事例も少ない. しかしながら, 実施工では, 裏込め注入により地盤の緩み度合は単純 にテールボイド発生に伴うシールドマシンとセグメン トのクリアランス分が緩むとは考えにくく, 裏込め注 入圧・量により緩み度合は変化するものと考えられる. また, 離隔に関しては0.04Dの離隔の施工 ${ }^{18}$ が実際に行 われており, 超近接の離隔に対する土圧の評価も重要 であると考えられる.

そこで, 本研究は, 施工時の一時的な荷重の影響と は別に長期的な影響を検証することとし，超近接の併 設シールドトンネルに作用する緩み現象のメカニズム を明らかにするために，トンネルに作用する鉛直・水 平土圧を直接計測可能な装置を用い，また土門ら ${ }^{19}$ によ る実験的研究の手法によりテフロンシートを用いて緩 み厚を変化させ, 緩み現象をテールボイドの発生によ る「緩み厚の影響」と併設トンネルの「離隔の影響」 について実験で把握するとともに，DEM解析により地 盤内応力・変形やトンネル作用土圧を解析的に評価し, 現場の計測データによる検証を試みる. 以上により， 水平に併設されるトンネルの緩み現象のメカニズムを 明らかにすることを目的とする。

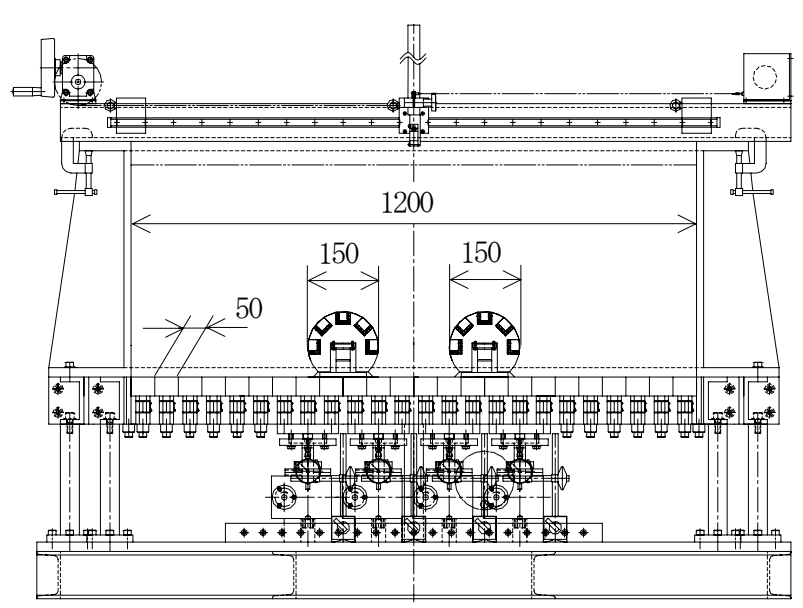

図-1 実験装置(単位 : mm)

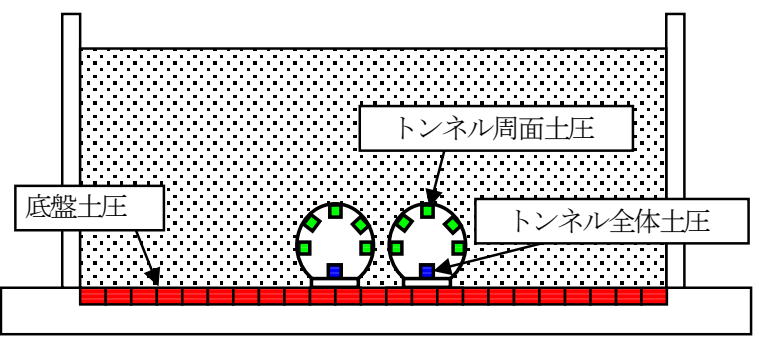

図-2 土圧計測位置

\section{2. 落し戸実験}

\section{（1）実験の特徴}

本実験の特徵を以下の1）～6)に述べる.

1）模擬地盤材料は，村山ら ${ }^{5), 6)}$ による研究より， $\phi$ $1.6 \mathrm{~mm}$ と $\phi 3.0 \mathrm{~mm}$ の円形のアルミ棒を重量比 $3: 2$ で混合したものを用いた.

2）トンネル模型は，実験上，計測装置を多数設置 した模型であり重量が重いことや土粒子のトン ネル底部への流動の影響を排除することを考慮 した結果，底盤に設置することが必要であった 為, Terzaghiの緩み土圧の影響範囲を実験領域と 仮定し，3/4円とした.

3） 3/4円のトンネル模型周面に所定の緩み厚となる ようにテフロンシートを巻き，それを引き抜く ことで法線方向に均一な緩みを与えた。

4） トンネル周面5箇所(トンネル直上, 左右 $45^{\circ}$ ・ $90^{\circ}$ ) に法線および接線方向の土圧をそれぞれ 直接計測可能なロードセルを設置し，さらにト ンネル全体に作用する鈆直全土圧を計測可能な ロードセルを模型底部に有したトンネル模型と した(図-2及び写真-1 (a), (c)参照).

5）セグメントの変形などによる影響を含まない, 純粋な掘削のみの周辺地盤の緩み現象を捉える ために，剛なトンネル模型を採用した。 


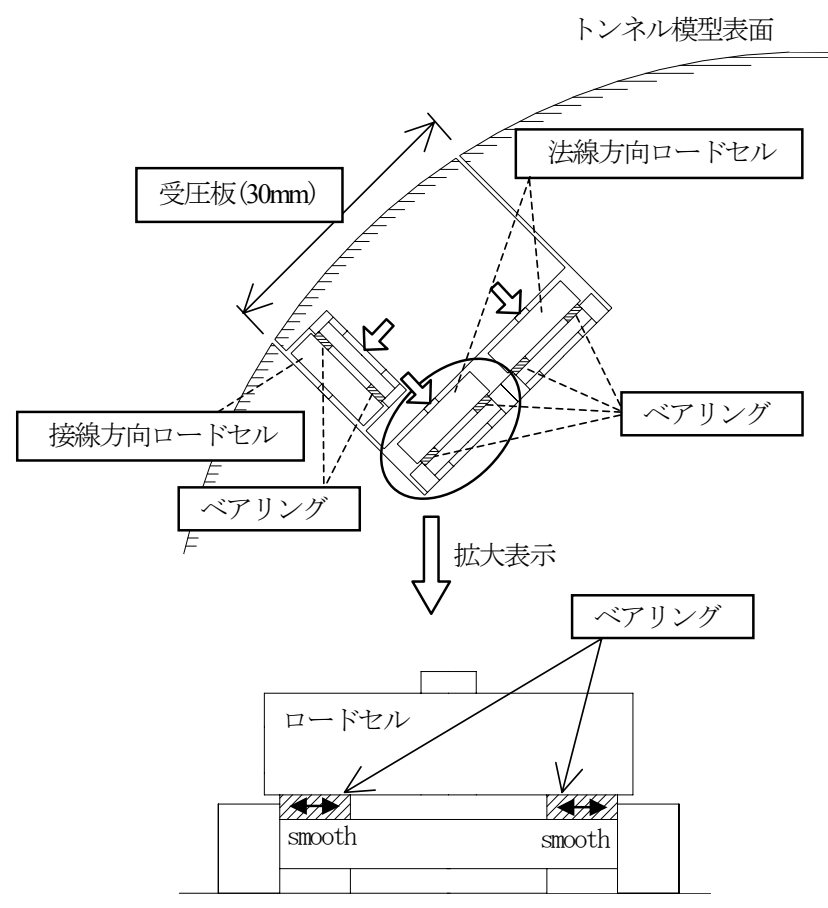

(a)トンネル周面土圧計詳細図（左 $45^{\circ}$ 位置）

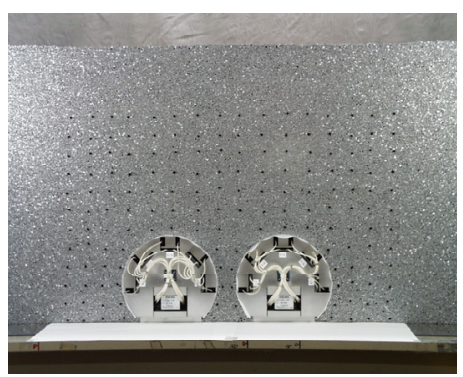

(b) 併設トンネル

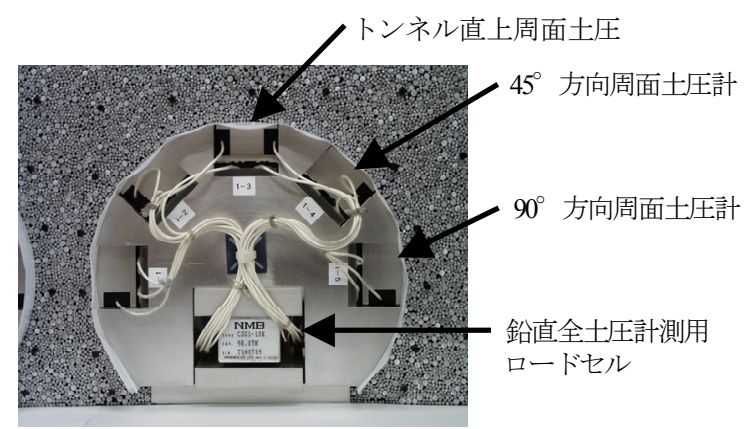

（c）トンネル模型

写真-1 アルミ棒積層体とトンネル模型

6) アルミ棒積層体内に標点を設置し(写真-1(b)), テールボイド発生前後の画像を解析することで, 地盤の現象を捉えられる装置を用いた。

したがって，本実験では，砂質地盤を模擬したアル ミ棒積層体内における円形併設トンネル上半部（詳細 にはトンネル周面3/4円）の周辺地盤の緩み現象を捉え ること，トンネル作用土圧を直接捉えることが可能で ある。
表-1 検討ケース（単位：mm)

\begin{tabular}{|c|c|c|c|c|}
\hline \multirow[b]{2}{*}{ 土被り } & \multirow[b]{2}{*}{ 離隔 } & \multicolumn{3}{|c|}{ 緩夕厚 } \\
\hline & & $\begin{array}{c}0.001 \mathrm{D} \\
(0.15) \\
\end{array}$ & $\begin{array}{c}0.005 \mathrm{D} \\
(0.75) \\
\end{array}$ & $\begin{array}{l}0.01 \mathrm{D} \\
(1.50) \\
\end{array}$ \\
\hline \multirow{3}{*}{$\begin{array}{c}2 \mathrm{D} \\
(300)\end{array}$} & $\begin{array}{l}0.2 \mathrm{D} \\
(30)\end{array}$ & (a) & - & $\bigcirc$ \\
\hline & $\begin{array}{c}0.3 \mathrm{D} \\
(45) \\
\end{array}$ & (C) & (a) & (a) \\
\hline & $\begin{array}{c}0.5 \mathrm{D} \\
(75)\end{array}$ & (a) & 0 & $\bigcirc$ \\
\hline
\end{tabular}

※○：実験および解析，○: 解析のみ

表-2 設定緩み厚とテフロンシート厚さの誤差

\begin{tabular}{|c|c|c|c|c|}
\hline \multicolumn{2}{|c|}{ 設定緩夕厚 } & \multicolumn{2}{|c|}{ テフロンシート(枚) } & \multirow{2}{*}{$\begin{array}{c}\text { 予備実験 } \\
\text { 緩夕厚誤差(\%) }\end{array}$} \\
\hline- & $\mathrm{mm}$ & $0.05 \mathrm{~mm}$ & $0.10 \mathrm{~mm}$ & \\
\hline $0.001 \mathrm{D}$ & 0.15 & 1 & 1 & 1.58 \\
\hline $0.005 \mathrm{D}$ & 0.75 & 1 & 7 & 5.38 \\
\hline $0.01 \mathrm{D}$ & 1.5 & 0 & 15 & 3.08 \\
\hline
\end{tabular}

\section{(2) 実験装置}

実験装置を図-1に，土圧計測位置を図-2に示す。実 験装置は底面に幅50mmのロードセルが敷き詰められて おり，鉛直荷重を計測できる。また，トンネル模型は， 直径 $150 \mathrm{~mm}$ の円形断面の上半部 $270^{\circ}$ のモデルでトンネ 儿直上と左右 $45^{\circ}, 90^{\circ}$ の位置に2方向計測できる長さ $30 \mathrm{~mm}$ の受圧板が取り付けられており，模型内部には模 型全体を支えるようにロードセルが設置されている. 周面作用土圧の計測は，写真-1(a)に示すように，受圧 板の中に3〜4個のロードセルが組み込まれており, 受 圧板に作用する接線方向土圧（面方向の摩擦）は，受 圧板を支える法線方向ロードセルに取り付けられたべ アリングにより接線方向ロードセルのみで計測を可能 とし，受圧面に作用する法線方向土圧は，接線方向口 一ドセルに取り付けられたベアリングにより法線方向 ロードセルのみで計測を可能としており，2方向の計測 が可能である (写真-1 (a), (c) 参照)。したがって, トン ネル模型は，接線・法線方向周面作用土圧と鉛直全土 圧が計測可能な二重の計測システムを有する装置とな っている.

\section{（3）実験条件および手順}

併設トンネルの位置関係として，超近接といわれる 0.2D，0.3D，0.5Dの3種類の離隔を設定した．また，テ 一ルボイドの発生による緩み厚は，テールボイドの 100\%相当の0.01Dとしたが，離隔0.3Dについては50\%相 当の $0.005 \mathrm{D}, 10 \%$ 相当の $0.001 \mathrm{D}$ を加えた 3 種類を設定した. 検討ケースを表-1に示す。実験の実施ケースは計5ケー スである.

本実験では，トンネル模型の3/4円の周面にテフロン 
シートを巻きつけそれを引き抜くことで地盤周辺に対 し法線方向に均一な緩みを与えるが, 予備実験におい て確実に3種類の緩み厚を発生させることが可能である ことを確認した. 予備実験は, 複数の厚さの異なるテ フロンシートを所定の厚さになるように組合せ，剛板 上に敷き, テフロンシート上に本実験の土被り圧相当 の荷重を載荷させ，その上に変位計（ダイヤルゲー ジ）を設置した後, テフロンシートを引き抜く方法で 行った. その結果, テフロンシートの厚さを最大 0.10mmに制限して, 表-2のように0.05mmと0.10 mmの厚 さを組合せることで，予備実験における計測厚さと設 定緩み厚の誤差を約 $5 \%$ 未満に抑えることができ，所定 の緩み厚を確保した。

実験手順は図-3に示寸通りである．各ステップ毎に 土圧を計測し，図-3(c)および(d)，(e) で画像を撮影し， テールボイド発生前後の画像処理を行うことで, 地中 変位を計測した. 初期状態(Step1)の作成は, 巻き出し厚 を $5 \mathrm{~cm}$ とし，底盤のロードセルで土被り圧を管理した。

併設トンネルは, 紙面左側を先行トンネル, 右側を 後行トンネルとして, 施工を行うこととし, 図-4のよ うに, 初期状態をStep1, 先行トンネル掘削をStep2, 後 行トンネル掘削をStep3 と定義する。なお，本実験は， 緩み現象による応力増分を計測することを目的として おり, 実験装置の制約上, 初期状態において, 予め後 行トンネル模型を設置した.

\section{（4）実験結果}

図-5～図-8に併設トンネル施工過程でのトンネル模 型に作用した鉛直全土圧比の履歷を示す. 図中の縦軸 は初期鉛直全土圧 (Step1時) に対する作用鉛直全土圧比 であり, 横軸は先行及び後行トンネル施工時の緩み量 である．図-5及び図-6は離隔0.3D (45m)のときの緩み 厚の違いによるものであり, それぞれ，先行トンネル， 後行トンネルの結果である. また, 図-7及び図-8は緩 み厚 $0.001 \mathrm{D}(0.15 \mathrm{~mm})$ のときのトンネル離隔の違いによ るものであり, それぞれ, 先行トンネル, 後行トンネ ルの結果である. 表-3には, 図-5及び図-6における応 力再配分を受ける側のトンネル模型の鉛直全土圧の増 加率（図-5及び図-6中の黒矢印）を示した.

図一において，先行側掘削時には，緩み厚が大きい ほど緩み土圧の影響により作用鉛直全土圧は減少し, 最終的な緩み量が異なる3ケースで鉛直全土圧の減少す る勾配はほぼ同じであった。 また後行側掘削時（併設 時）は, 後行トンネル掘削の影響を受け, 緩み厚が大 きいほど応力再配分の影響が顕著に表れる結果となっ た.

図-6において，先行側掘削時には，後行トンネル模

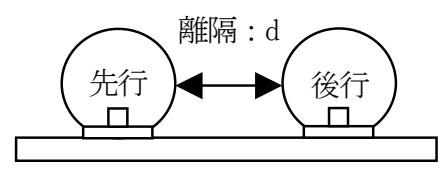

(a) シールド模型が所定の離隔を保つように設置する.

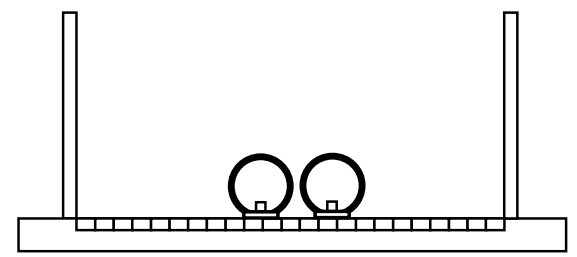

(b) シールド模型にテフロンシートを設置する.

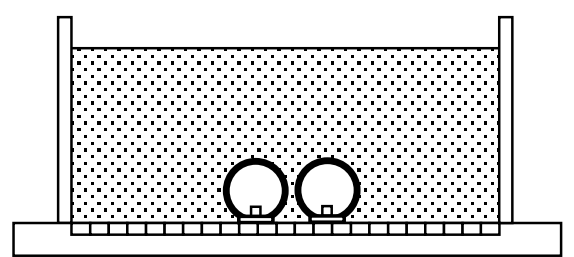

（c）周辺地盤作製(アルミ棒積層体を積み込む)および標点を 設置する.

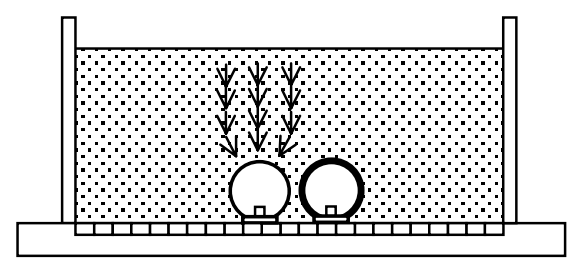

（d）先行側のテフロンシートを引抜く（先行側掘削）.

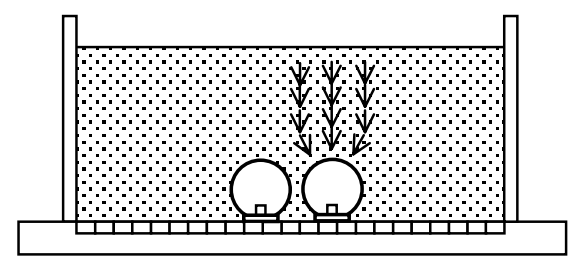

（e）後行側のテフロンシートを引抜く（後行側掘削）。

図-3 実験手順

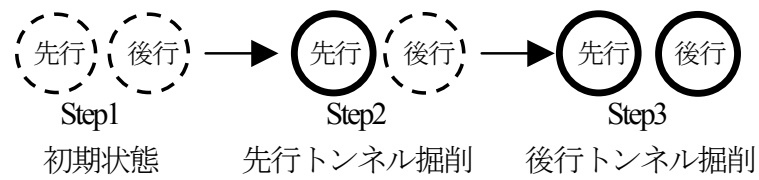

図-4 施工ステップ

型に作用する鉛直全土圧は先行トンネル掘削による応 力再配分の影響を受けて増加し, 最終的な緩み量が異 なる3ケースで鉛直全土圧の増加する勾配はほぼ同じで あった．また，併設時は後行トンネル掘削により緩み 土圧が生じ作用鉛直全土圧が減少している.

表-3より, 図-5の後行側掘削時 (….) と図-6の先行側掘 削時 (一) は共に応力再配分を受け作用鉛直全土圧は増 加していることがわかり，トンネル周辺地盤が緩んで いる時の方が，緩んでいない時よりも鉛直全土圧増加 率が大きくなるという結果となった. 


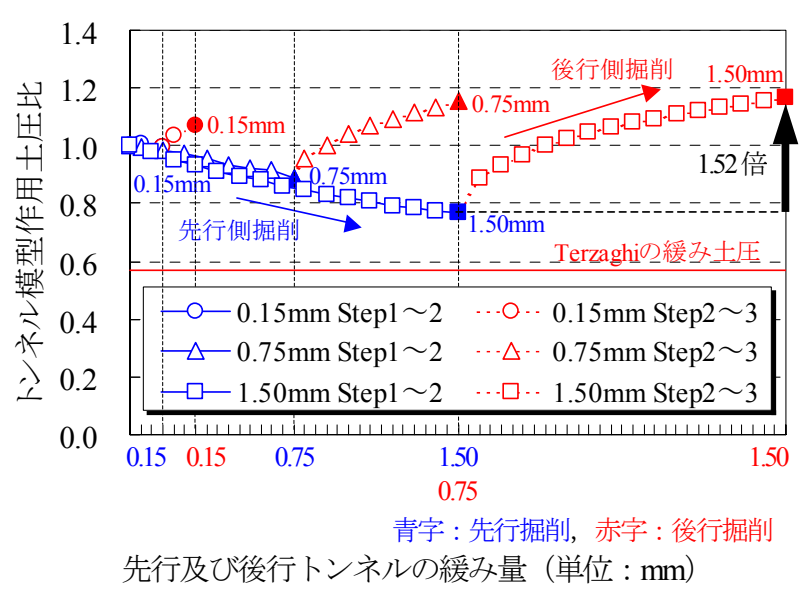

図-5 先行トンネル作用土圧比の履歴 (離隔0.3Dのときの緩み厚の影響)

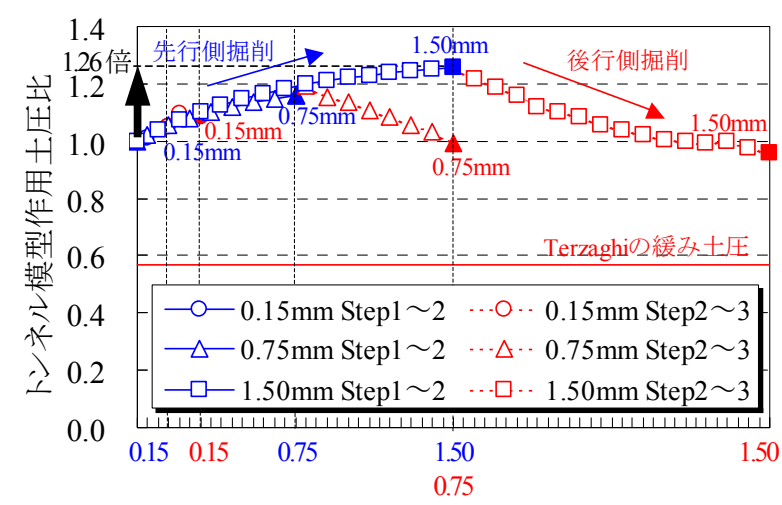

青字: 先行掘削, 赤字: 後行掘削 先行及び後行トンネルの緩み量（単位：mm）

図-6 後行トンネル作用土圧比の履歴 (離隔 $0.3 \mathrm{D}$ のさの緩み厚の影響)

表-3 応力再配分を受けるトンネル模型の土圧増加率

\begin{tabular}{|c|c|c|}
\hline $\begin{array}{c}\text { 応力再配分を受けるト } \\
\text { ンネル模型 }\end{array}$ & 周辺地盤状態 & 土圧増加率 \\
\hline $\begin{array}{c}\text { 図-5 先行トンネル模型 } \\
\text { 後行側掘削(.....) }\end{array}$ & 緩んでいる & 1.52 \\
\hline $\begin{array}{c}\text { 図-6 後行トンネル模型 } \\
\text { 先行側掘削( }\end{array}$ & 緩んでいない & 1.26 \\
\hline
\end{tabular}

図-7及び図-8より，応力再配分による鉛直全土圧は， 緩み厚が $0.001 D$ とさいことから, 先行及び後行トンネ ル共に離隔の違いにより顕著な差は生じなかった.

図-9に離隔0.3Dの時の併設トンネル施工過程における 先行トンネルに作用する法線方向周面土圧の分布困を 示す. 図中 (a) は先行トンネル掘削 (Step1～Step2)時, (b) は後行トンネル掘削(Step1～Step3)時，（c）は後行トンネ ル掘削(Step2～Step3)時の土圧増分比を緩み厚毎に示した ものである．本図より，先行トンネルを掘削すること により緩み土圧の影響で先行トンネルの土圧は初期状 態の土圧よりも減少していることが分かる（図中 (a)）. 先行トンネル掘削時は，本実験の特徴でもあるが，卜

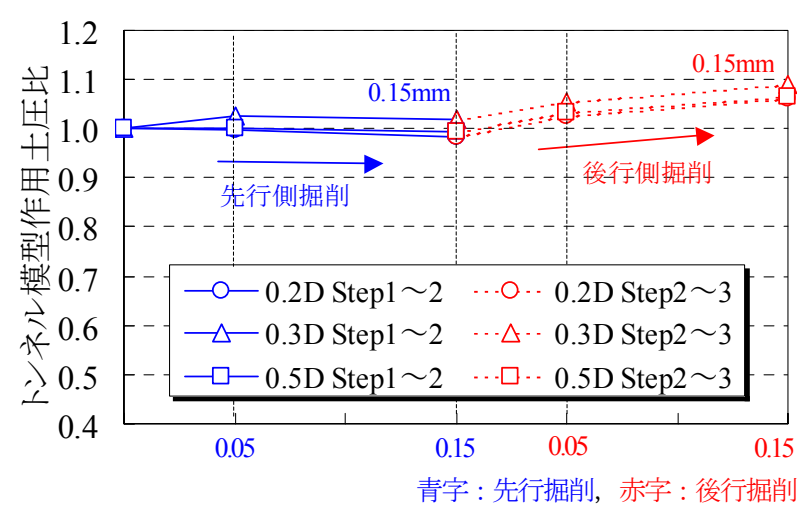

先行及び後行トンネルの緩み量（単位: $\mathrm{mm}$ )

図-7 先行トンネル作用土圧比の履歴

(緩み厚0.001Dのときのトンネル離隔の影響)

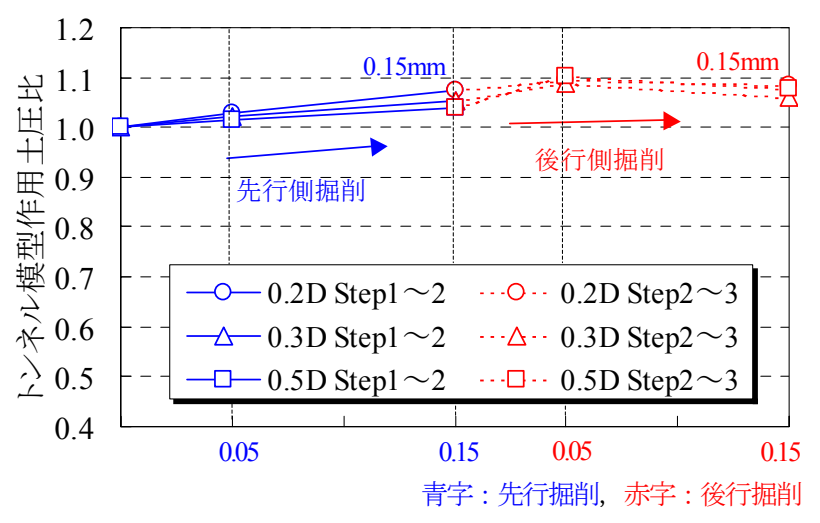

先行及び後行トンネルの緩み量（単位 : mm)

図-8 後行トンネル作用土圧比の履歴

(緩み厚0.001Dのときのトンネル離隔の影響)

ンネル模型が剛体であるため変形を生じず，トンネル 頂部では減少率が小さい結果となった。 また，左右 $45^{\circ}$ の位置のロードセルでは, 緩み厚が最小の $0.001 \mathrm{D}(0.15 \mathrm{~mm})$ のケースで右 $45^{\circ}$ の土圧が大きいが，よ り大きな影響が生じる0.005D $(0.75 \mathrm{~mm})$ 及び $0.01 \mathrm{D}(1.50 \mathrm{~mm})$ のケースでは生じていないことから，有意な傾向では ないと判断できる. 後行トンネルを掘削することによ り忘力再配分の影響で, 併設トンネル近接部 $45^{\circ}$ の位 置に設置されているロードセルで最も大きな土圧増加 が生じ，トンネル頂部においても土圧が増加した。 ト ンネル近接部 $90^{\circ}$ の位置のロードセルは, 後行トンネ ルを掘削することにより土圧が減少する結果となった. 本図に示した土圧増分比は，緩み厚が大きいほど掘削 によりトンネルに与える影響が大きいことを示してい ることが分かる。 


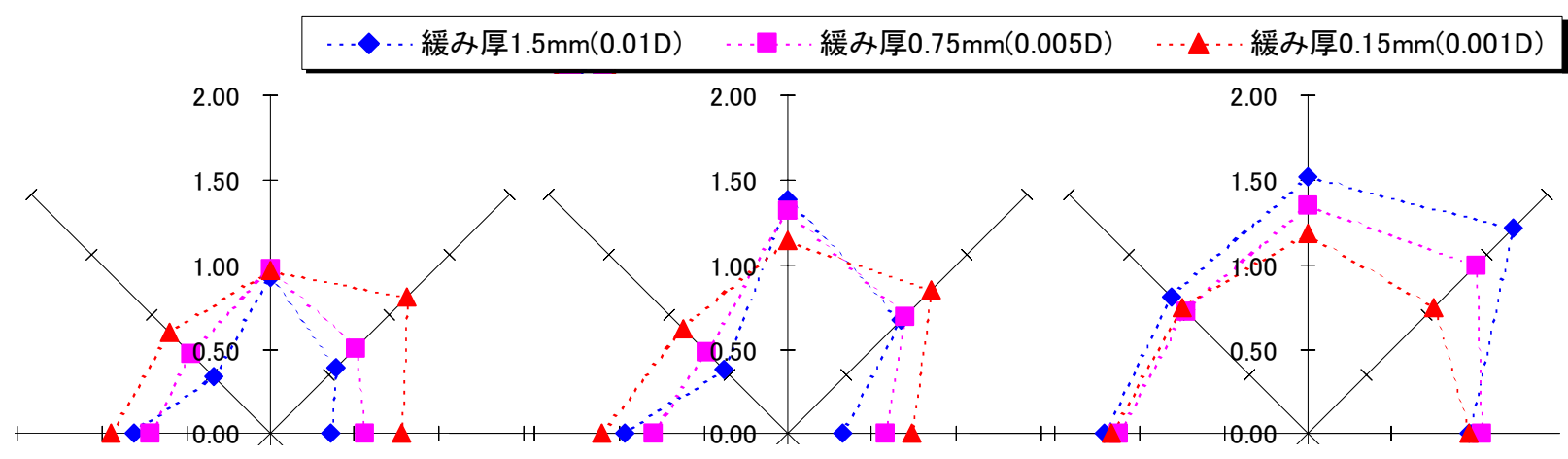

(a) Step1 Step2

(b) Step1 Step3

(c) Step2 Step3

図-9 先行トンネル法線方向周面作用土圧分布（離隔 0.3D）

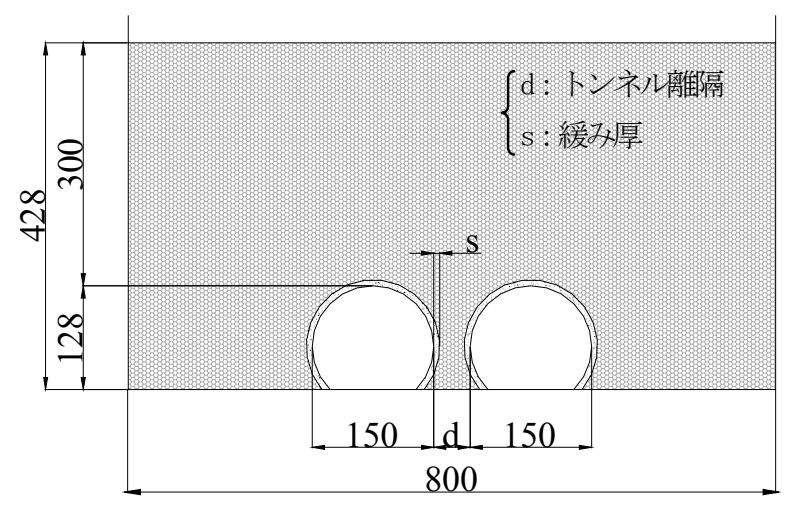

図-10 解析モデル (単位 : $\mathrm{mm}$ )

\section{3. 個別要素法 (DEM) 解析}

\section{（1）緩み現象とDEM解析}

DEM解析は，1971年にPeter A.Cundallが，亀裂性岩盤 に対する解析手法としてDBM(Discrete Block Method)を提 案した ${ }^{20)} こ と に$ 始まり，1976年頃からDBMが岩石ブロ ックなどばかりでなく, 土粒子の集合体として地盤に も適用できることを示唆した ${ }^{21)}$. 実際には1979年の論文 で粒状体に適用して，その名称もブロックから要素へと 一般化させてDEM(Distinct Element Method) と改称した ${ }^{22)}$. それ以来，DEMを用いた種々の研究は行われているが， トンネル掘削に関する研究においても, 多く使われて いる例えば(6), 23), 24), 25), 26).

解析的に緩み土圧を求める方法として, 非線形FEM 解析, ジョイント要素を用いた弾塑性解析や, テール ボイドにギャップ要素を用いた解析などがあるが，既 往の研究 ${ }^{20)}$ により, 大変形領域の緩み現象を上手く説明 する方法としてDEM解析の利用が提案されている.

DEM解析は，テールボイド発生による砂質地盤 (粒状 体)の緩みをシミュレーション解析する場合に, せん断 帯に集中する大きなひずみや応力の集中を考慮する場 合に有効と考えられている，そこで，シミュレーショ ン解析は，DEM解析を採用することとした。

\begin{tabular}{|c|c|c|}
\multicolumn{2}{|c|}{ 表-4 要素数 } \\
\hline & $\phi 1.6 \mathrm{~mm}$ & $\phi 3.0 \mathrm{~mm}$ \\
\hline 径別要素数 & 81351 & 15427 \\
\hline 全体要素数 & \multicolumn{3}{|c|}{96778} \\
\hline
\end{tabular}

表 -5 解析定数

\begin{tabular}{|c|c|c|}
\hline \multicolumn{2}{|c|}{ 定数名 } & 值 \\
\hline \hline \multirow{2}{*}{ ばね定数 $(\mathrm{N} / \mathrm{m})$} & 法線方向 & $6.00 \mathrm{E}+07$ \\
\cline { 2 - 3 } & 接線方向 & $2.00 \mathrm{E}+07$ \\
\hline \multirow{2}{*}{ 粘性係数 $(\mathrm{N} ・ \mathrm{sec} / \mathrm{m})$} & 法線方向 & $2.70 \mathrm{E}+02$ \\
\cline { 2 - 3 } & 接線方向 & $1.60 \mathrm{E}+02$ \\
\hline \multicolumn{2}{|c|}{ 回転拘束パラメータ } & 10 \\
\hline \multicolumn{2}{|c|}{ 要素密度 $\left(\mathrm{kg} / \mathrm{m}^{3}\right)$} & 2700 \\
\hline \multicolumn{2}{|c|}{ 要素摩擦角 $(\mathrm{deg})$} & 16 \\
\hline \multicolumn{2}{|c|}{ 内部摩擦角 $(\mathrm{deg})$} & 30 \\
\hline \multicolumn{2}{|c|}{ 時間間隔 $(\mathrm{sec})$} & $1.00 \mathrm{E}-06$ \\
\hline \multicolumn{2}{|c|}{ 解析ステップ数 } & 5400000 \\
\hline \multicolumn{2}{c}{}
\end{tabular}

\section{(2) 解析概要}

\section{a) 解析モデル}

解析モデルを，図-10に示す，本解析では，落し戸実 験において用いたトンネル模型をスケール1:1でモデル 化し, 重力場で解析した. 解析に用いた地盤要素は, 落し戸実験で用いたアルミ棒と同じ $\phi 1.6 \mathrm{~mm}$ と $\phi 3.0 \mathrm{~mm}$ の要素を重量比3:2で混合したものを用いた．要素数は， 実験における初期底盤応力から積層体の単位体積重量 を求め, 目標間隙比を設定し, 表-4のように決定した。 また，要素の密度はアルミの密度 $\rho=2700\left(\mathrm{~kg} / \mathrm{m}^{3}\right)$ とし， 積層体の内部摩擦角はアルミ棒積層体の内部摩擦角 $\phi$ $=30(\mathrm{deg})$ と同じ值を用いた.

\section{b) 解析ケース}

解析ケースは表-1のように，実験の5ケースに加えて， 計8ケースである.

\section{c）要素間の各定数}

解析に用いた定数を表-5に示す. DEM解析は，図-11 のように, 各円形要素に作用する外力として, 要素の 


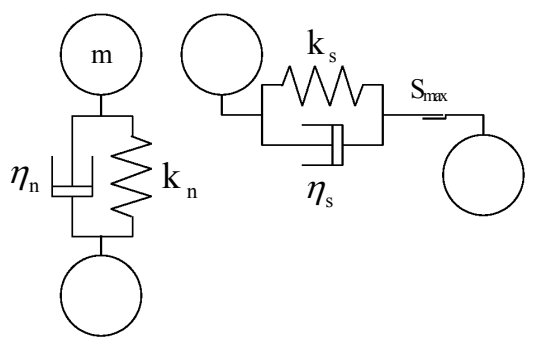

図-11 接触力学モデル

接触時のみばねとダッシュポットを介して作用する接 触力と, 物体力としての慣性力及び自重等を考えてお り, 各要素の動的挙動を差分法により追跡している. また, 要素の接触面の接線方向にはCoulombの摩擦条件 が仮定されており, 要素間摩擦角 $\phi$, 粘着力Ceにより 最大せん断応力 $\mathrm{S}_{\max }$ が次式(1)で定義される.

$$
\mathrm{S}_{\max }=\mathrm{Ce}+\mathrm{F} \cdot \tan \psi
$$

ここに，Fは要素中心方向の作用力である.

要素間のば社定数及び粘性係数は木山ら ${ }^{25)}$ の手法によ り式(2)〜(5)を用いて求めた.

$$
\begin{gathered}
\mathrm{k}_{\mathrm{n}}=\frac{\pi \mathrm{E}}{2\left(1-v^{2}\right)\{1.5+2 \ln (4 \mathrm{r} / \mathrm{b})\}} \\
\mathrm{k}_{\mathrm{s}}=\mathrm{s} \cdot \mathrm{k}_{\mathrm{n}} \\
\eta_{\mathrm{n}}=2 \sqrt{\mathrm{m} \cdot \mathrm{k}_{\mathrm{n}}} \cdot \mathrm{h} \\
\eta_{\mathrm{s}}=2 \sqrt{\mathrm{m} \cdot \mathrm{k}_{\mathrm{s}}} \cdot \mathrm{h}
\end{gathered}
$$

ここに， $\mathrm{k}_{\mathrm{n}}$ 及び $\mathrm{k}_{\mathrm{s}}$ はそれぞれ法線方向及び接線方向 のばね定数であり, 本解析では, 解析時間の短縮や解 析の収束性を考慮し, 式(2)及び(3)より求まった值に $10^{-2}$ を乗じた值を用いた．Eは要素のヤング係数であり，ア ルミのヤング係数 $\mathrm{E}=7.0 \times 10^{4}(\mathrm{MPa})$ を用い, $v$ は要素の ポアソン比であり $v=0.3$ とした. また, $\mathrm{r}$ は要素の平均 半径であり, bは接触幅であり次式により求まる.

$$
\mathrm{b}=\sqrt{\frac{4 \mathrm{r}\left(1-v^{2}\right)}{\pi \mathrm{E}}}
$$

sは，逢減率であり，文献16)より $\mathrm{s}=1 / 3$ と仮定した。 $\eta_{\mathrm{n}}$ 及び $\eta_{\mathrm{s}}$ は，それぞれ法線方向及び接線方向の粘性係数 であり, 質量mとば初からなる1質点系の臨界減衰定数 に減衰定数hを乗じた式である. 減衰定数hは，文献28) より経験的に $=0.2$ とした.

本解析では, 粒子接点でのモーメント伝達を考慮し ている. 粒状体の変形は粒子の回転と移動により生ず るものであるが, 粒子の回転が粒状体の変形に及ぼす 影響が大きいという過去の研究報告もある。そこで, 岩下ら ${ }^{28), 29)}$ の研究に基づく粒子の回転剛性を導入し, 粒

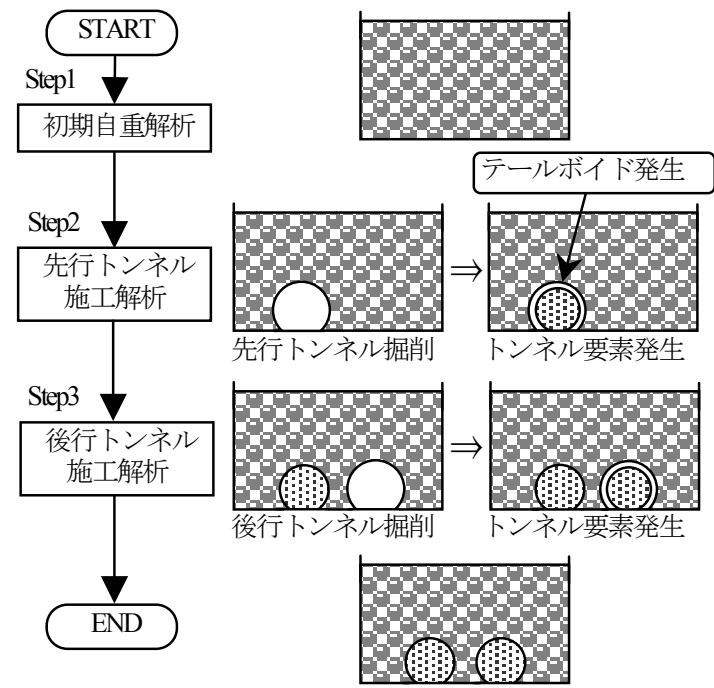

図-12 解析手順

子の仮想接触面を10倍として評価するように，そのパラ メータである $\alpha$ を $\alpha=10$ として，粒子の回転を制限した。

以上のように各種定数を設定し, 要素間の各定数を 解析に採用したことで, 後述する2軸試験において地盤 定数を所期の值として設定することができ, 初期自重 解析においても土層の間隙比を目標間隙比とすること ができた. また, 解析のステップ毎にテールボイドを 発生させるための要素の除去を行った際に, 要素の飛 出し等の不安定現象も生じなかった.

\section{d) 解析手順}

解析手順は，図-12のように初期自重解析 (Step1)を行 い, 先行トンネル掘削解析 (Step2), 後行トンネル掘削 解析 (Step3) を行う。初期自重解析は, $\phi 1.6 \mathrm{~mm}$ と $\phi$ 3.0mmの要素を重量比3:2で混合したものを所定の個数 を乱数発生させ, 粒子の移動速度が 0 付近まで収束する まで繰返し計算を行った。 トンネル掘削の際には, 掘 削外径に抵触する要素を除去するとともに, 中心にト ンネルに相当する要素を発生させ，テールボイドに相 当する要素のみを除去することとした，要素の除去は， 掘削外径内に完全に含まれる要素は除去し, 掘削外径 と交わる要素については掘削外径に接するように要素 径を縮小した。 なお，実験においては予め後行トンネ ル模型を設置していたが, 解析においては, より現実 に近い挙動を捉えるため, 先行トンネル掘削時は単設 モデルとした.

\section{e) 応力評価}

DEM解析では, 要素間の作用力が集中力として評価 される. そのため, 要素間に作用している集中力を連 続場としての応力に換算する必要がある. そこで, 図13のように要素モデルを格子状に分割し, 格子要素各 辺の垂直方向応力 $\sigma_{\mathrm{ni}}$ 及びせん断応力 $\sigma_{\mathrm{ti}}(\mathrm{i}=1 \sim 4)$ は, 各 格子点間の辺を通過する要素間の作用ベクトルの合計 


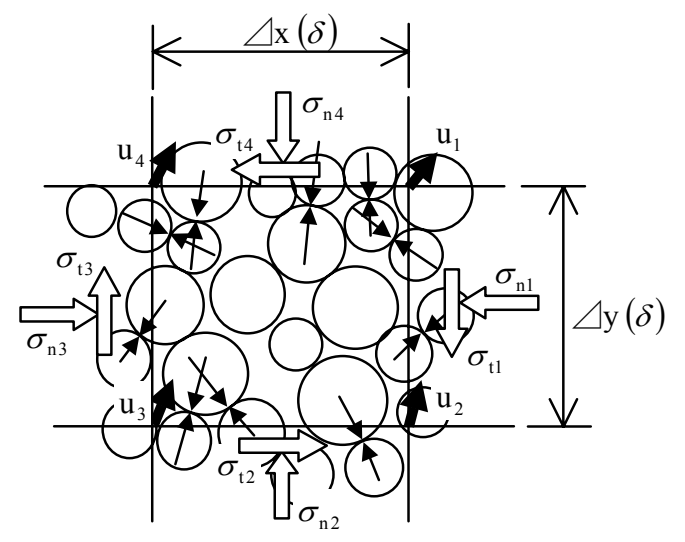

図-13 応力評価

值を各格子点間距離で除して求めた ${ }^{16)}$ ，すなわち，格子 の各辺に作用する応力は式(7a), (7b)により求まり, 式 (8a)〜(8c)を用いて最終的に格子中心の応力を求めた.

$$
\begin{aligned}
& \sigma_{\mathrm{nj}}=\sum_{\mathrm{i}=1}^{\mathrm{n}} \mathrm{P}_{\mathrm{ni}}^{\mathrm{j}} / \delta \\
& \sigma_{\mathrm{tj}}=\sum_{\mathrm{i}=1}^{\mathrm{n}} \mathrm{P}_{\mathrm{ti}}^{\mathrm{j}} / \delta
\end{aligned}
$$

ここに, $\mathrm{P}_{\mathrm{ni}}^{\mathrm{j}}$ は要素間の格子鉛直方向力, $\mathrm{P}_{\mathrm{ti}}^{\mathrm{j}}$ は要素間の 格子せん断方向力, $\delta$ は格子間隔である.

$$
\begin{gathered}
\sigma_{\mathrm{x}}=\left(\sigma_{\mathrm{n} 1}+\sigma_{\mathrm{n} 3}\right) / 2 \\
\sigma_{\mathrm{y}}=\left(\sigma_{\mathrm{n} 2}+\sigma_{\mathrm{n} 4}\right) / 2 \\
\tau_{\mathrm{xy}}=\sum_{\mathrm{k}=1}^{4} \sigma_{\mathrm{tk}} / 4
\end{gathered}
$$

ここに, $\sigma_{\mathrm{x}}$ は格子中心の水平応力， $\sigma_{\mathrm{y}}$ は格子中心の鉛 直応力, $\tau_{\text {xy }}$ は格子中心のせん断応力である.

\section{f）ひずみ評価}

DEM解析では各要素は剛体であり変位挙動は算出で きるがひずタは直接算出することができない.しかし 応力の場合と同様通常は，地盤を連続体として扱いひ ずみと応力によってその挙動を記述する場合が多く,

応力と同様にひずみに関しても個々の要素変位から算 出する必要がある。そこで図-13のように格子状に分割 した4隅の変位 $\mathrm{u}_{\mathrm{i}}(\mathrm{i}=1$ ～4) を計算し，式(9a)〜(9c)を用いて 格子のひずみを求めた。

$$
\begin{aligned}
\varepsilon_{x}= & \left(-u_{1 x}+u_{2 x}+u_{3 x}-u_{4 x}\right) /(2 \Delta x) \\
\varepsilon_{y}= & \left(-u_{1 y}-u_{2 y}+u_{3 y}+u_{4 y}\right) /(2 \Delta y) \\
\gamma_{x y}= & \left(-u_{1 y}+u_{2 y}+u_{3 y}-u_{4 y}\right) /(2 \Delta x)+ \\
& \left(-u_{1 x}-u_{2 x}+u_{3 x}+u_{4 x}\right) /(2 \Delta y)
\end{aligned}
$$

ここに， $\varepsilon_{\mathrm{x}}$ は格子の水平方向の直ひずみ， $\varepsilon_{\mathrm{y}}$ は格子の 鉛直方向の直ひずみ， $\gamma_{\mathrm{xy}}$ は格子のせん断ひずみであり， $\Delta \mathrm{x}$ およ゙ $\Delta \mathrm{y}$ は格子間隔である.なお，格子間隔は $20 \mathrm{~mm}$ と，格子内の粒子は約115個となるように設定

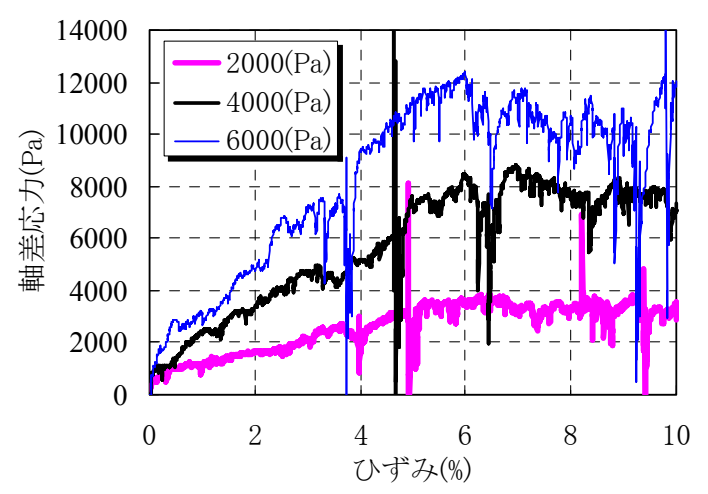

図-14 2軸試験結果

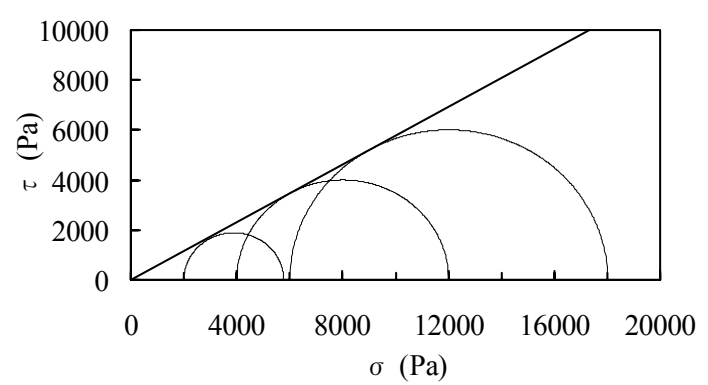

図-15 Mohrの応力円と破壊線

した.

\section{g）トンネルに作用する土圧評価}

解析手順で示したように, DEM解析においてトンネ ル模型は, トンネル径と同一の要素として与え, 移動 は拘束した. その要素と地盤要素の接触力をトンネル 周面作用土圧として評価した。

また，トンネルに作用する鉛直全土圧は，トンネル 周面作用土圧の鉛直成分の和として評価した。

\section{(3) 2軸試験}

Terzaghi $^{2)}$ や村山・松岡 ${ }^{(6)}$ の理論における緩み土圧は, 砂質地盤の内部摩擦角 $\phi$ によって変化するものとして いる. したがって，テールボイドの発生によるシール ドトンネル周辺地盤の応力再配分等をシミュレーショ ンする上で内部摩擦角は一番重要なパラメータである. 本研究においては，アルミ棒積層体の内部摩擦角を $\phi=30(\mathrm{deg})$ に合わせるため, 要素数3181個のモデルを用 いて2軸試験を実施した．要素間の摩擦角 $\phi$ を数ケース 設定し，拘束圧を2000(Pa)，4000(Pa)，6000(Pa)の3ケース について解析を行った. その結果, $\phi=30(\mathrm{deg})$ に対する 最適な $\phi$ を16(deg) と決定した. 応力〜ひずみ関係は図一 14，Mohrの応力円は図-15のようになり，DEM解析にお ける仮想地盤の内部摩擦角が30(deg)であることを確認 した. 


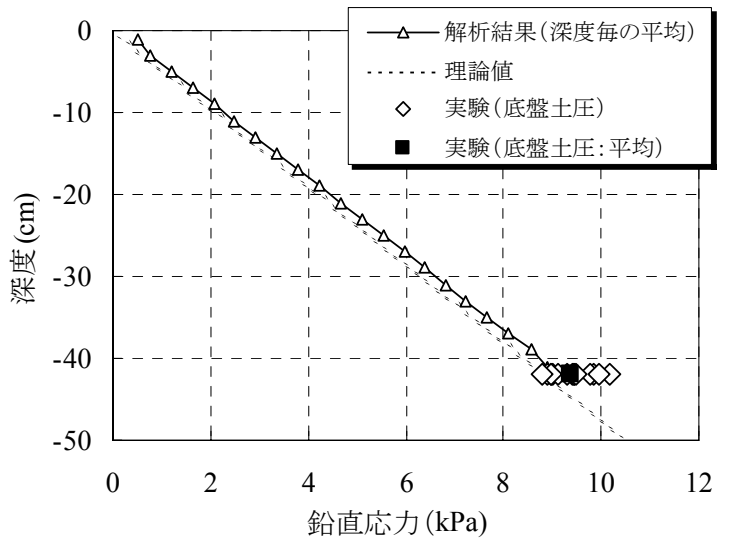

図-16 初期自重解析結果

\section{（4）初期自重解析結果}

図-16に初期自重解析結果を示寸. 図中の解析結果は 深度毎の格子要素の応力の平均值であり, 実験值は底 盤に敷き詰められているロードセルの值である。なお， 図中の実験值は，トンネル模型が設置されていない底 盤のロードセルの值（凡例 : 実験（底盤土圧））及び, その值の平均值（凡例 : 実験（底盤土圧 : 平均））を 示している. 本図より, 解析結果, 実験結果及び理論 值は概ね一致していることが分かる.

\section{（5）緩み厚 $0.01 \mathrm{D}$ ・離隔0.3Dの解析結果 \\ a）地盤変状}

図-17及び図-18に解析結果と実験結果の変位等高線 図を示す，図-17は先行トンネル掘削 (Step1～Step2) 時の 変位増分であり, 図-18は後行トンネル掘削 (Step2〜 Step3) 時の変位増分である. 図-17は, 先行トンネル掘 削時であるため周辺地盤は緩んでいないことから, 解 析結果では変位はトンネル直上に生じているが，実験 結果では離隔が狭いことから, 後行トンネルを予め設 置していたことによる影響で，トンネルの直上の後行 トンネル側に生じている. 図-18は, 先行トンネル掘削 により先行側周辺地盤が緩んでいることから, 実験結 果及び解析結果共に先行トンネルと後行トンネルの近 接箇所上部で先行トンネル掘削時より大きな変位が生 じている.

図-19に積層体表面沈下分布の各ステップ毎の増分を 示した. 図-19(a)の初期状態から先行トンネル掘削時 の増分は先行トンネルのほぼ直上で最大沈下が生じて おり，図-17と同様に，実験では後行トンネルが設置し てあることによりやや左寄りに沈下が生じている．図19 (b) の先行トンネル掘削後から後行トンネル掘削時の 増分は後行トンネル直上で最大沈下が生じており, 沈 下量は先行トンネル掘削時の周辺地盤の緩みの影響で 図-19(a)の結果よりも大きな值となっている．図-19(a) 及び(b)の沈下曲線はほぼ対称なモードとなり, 掘削し

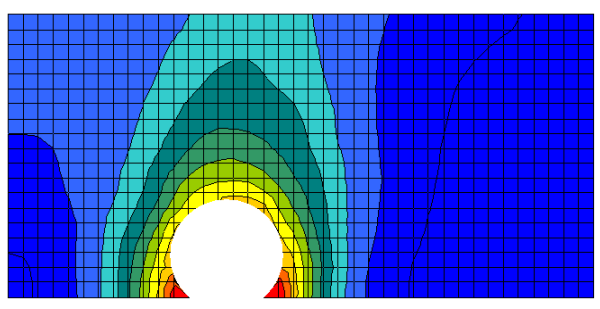

(a) 解析結果

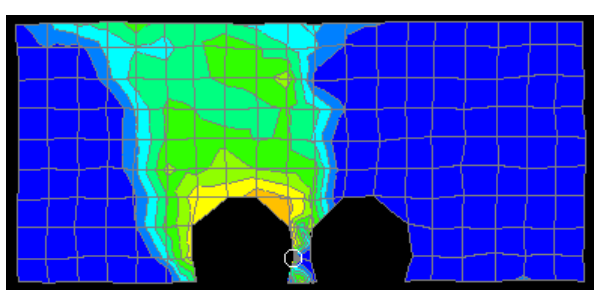

(b) 実験結果

$\square$ 0.0E+0-2.0E-4 $\square 2.0 \mathrm{E}-4-4.0 \mathrm{E}-4 \quad \square$ 4.0E-4-6.0E-4 $\square$ 6.0E-4-8.0E-4 $\square .0 \mathrm{E}-4-1.0 \mathrm{E}-3 \quad \square 1.0 \mathrm{E}-3-1.2 \mathrm{E}-3 \quad \square 1.2 \mathrm{E}-3-1.4 \mathrm{E}-3 \quad \square 1.4 \mathrm{E}-3-1.6 \mathrm{E}-3$ $\square 1.6 \mathrm{E}-3-1.8 \mathrm{E}-3 \quad \square 1.8 \mathrm{E}-3-2.0 \mathrm{E}-3 \quad \square 2.0 \mathrm{E}-3-2.2 \mathrm{E}-3$ (単位 : $\mathrm{m}$ )

図-17 先行トンネル掘削(Step1〜Step2)のときの 変位等高線（緩夕厚 $0.01 \mathrm{D} ・$ 離隔 $0.3 \mathrm{D}$ )

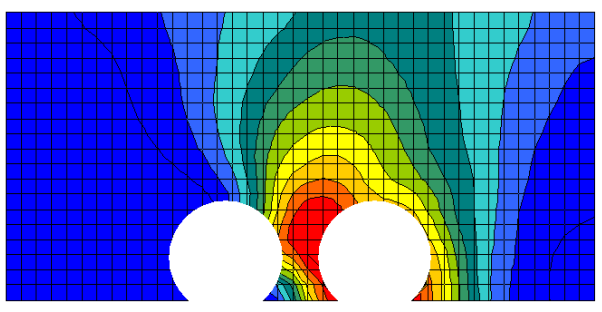

(a) 解析結果

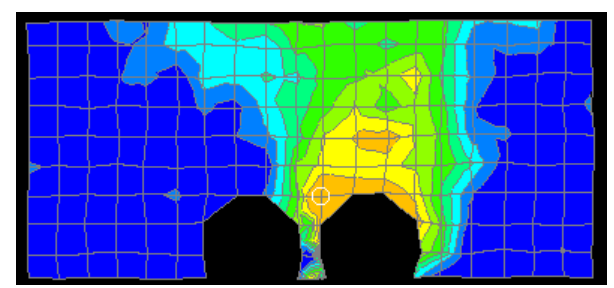

(b) 実験結果

口 $0.0 \mathrm{E}+0-2.0 \mathrm{E}-4 \quad$ 2.0E-4-4.0E-4 $\square$ 4.0E-4-6.0E-4 $\square 6.0 \mathrm{E}-4-8.0 \mathrm{E}-4$ $\square$ 8.0E-4-1.0E-3 $\square 1.0 \mathrm{E}-3-1.2 \mathrm{E}-3 \quad \square 1.2 \mathrm{E}-3-1.4 \mathrm{E}-3 \quad \square 1.4 \mathrm{E}-3-1.6 \mathrm{E}-3$ $\square$ 1.6E-3-1.8E-3 $\square 1.8 \mathrm{E}-3-2.0 \mathrm{E}-3 \quad \square 2.0 \mathrm{E}-3-2.2 \mathrm{E}-3$ (単位: $\mathrm{m}$ )

図-18 後行トンネル掘削 (Step2～Step3増分)のときの 変位等高線（緩夕厚 $0.01 \mathrm{D} ・$ 離隔 $0.3 \mathrm{D}$ )

たトンネルの直上で表面沈下の最大值が生じる結果と なった．図-19(c) は初期から後行トンネル掘削時の沈 下を示したものであり，最大沈下は先行トンネルと後 行トンネルの中央付近で発生した。これは，先行トン ネル掘削時の周辺地盤の緩みにより形成されたアーチ が後行トンネル掘削により2つのトンネルを跨ぐような アーチに再形成されたからであると考えられる.

\section{b) 地盤内応力}

図-20に底盤土圧の各ステップ毎の増分を示した．先 行トンネル及び後行トンネルのテールボイド発生によ 


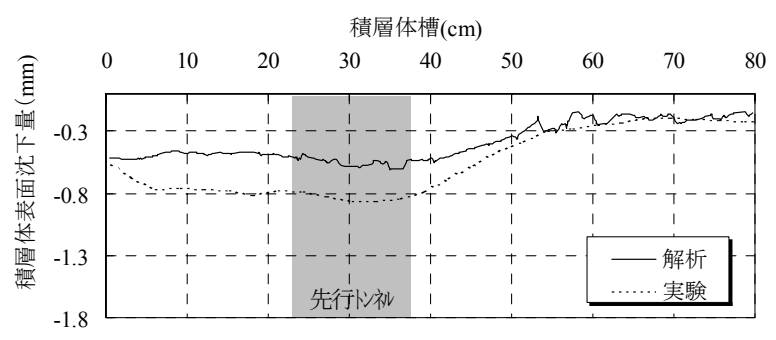

(a) 先行トンネル掘削 $($ Step1～Step2)

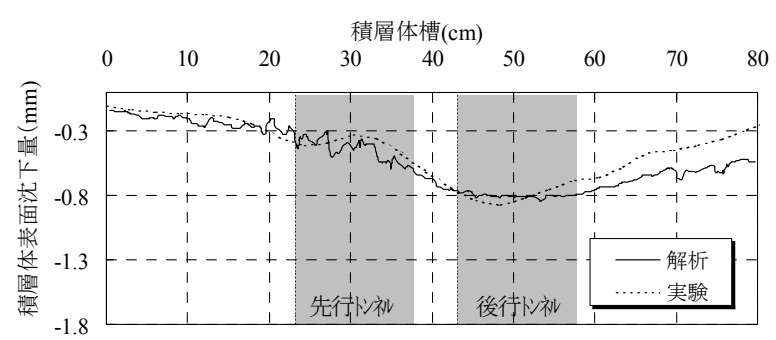

(b) 後行トンネル掘削 (Step2～Step3増分)

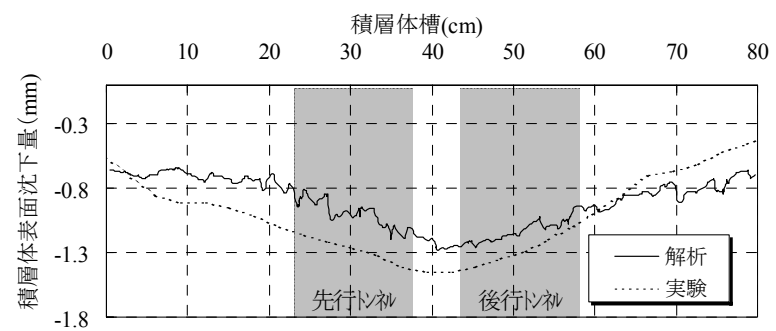

(c) 後行トンネル掘削 (Step1～Step3)

図-19 積層体表面沈下（緩み厚 $0.01 \mathrm{D} ・$ 離隔 $0.3 \mathrm{D}$ )

り底盤土圧は，掘削したトンネル周面付近で減少し， 約 $0.5 \mathrm{D}$ トンネル側方から増加している. また, 解析結 果とほぼ一致しており, 解析による増分応力の評価が 可能であると考えられる.

図-21 (a)，(b) は，解析ステップにおける先行トンネ ル及び後行トンネル掘削に伴う緩みによる最大せん断 応力の初期状態からの増分を示したものである. 後述 するアーチング効果によるトンネル周方向応力増加と 半径方向応力の減少によって主応力差が広がり, 図21 (a)では，先行トンネルを覆うように最大せん断応力 が生じていることが分かる. 図-21 (b) では，先行トン ネルと後行トンネルを覆うように，その外側の両足下 と両トンネル頂部に最大せん断応力が生じている.こ れは，超近接でトンネルを施工すると，a）で述べたの と同様に，後行トンネル掘削による応力の再配分によ り, 先行トンネル左側足下の最大せん断応力は緩和さ れ, 後行トンネル右側足下と各トンネル頂部で最大せ 儿断応力が増加している.これは，後述する図-24の主 応力（もしくは主応力差）の (a) から (b)への変化と整 合している.

図-22は，先行トンネル及び後行トンネル掘削後の側 方土圧係数 $\lambda\left(\mathrm{K}_{0}\right)$ を示したものである. 図-22(a) は, 先

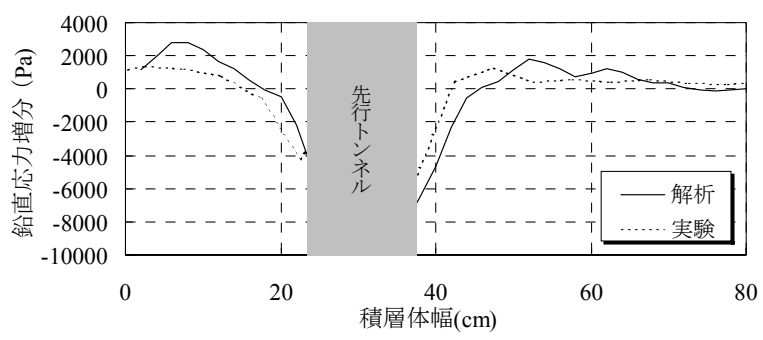

（a）先行トンネル掘削 (Step1～Step2)

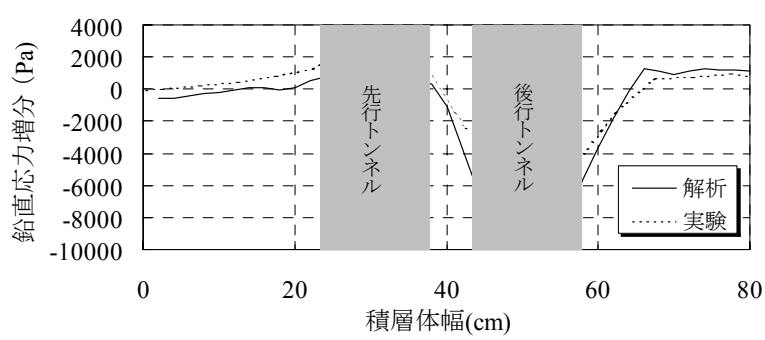

(b) 後行トンネル掘削 (Step2〜Step3増分)

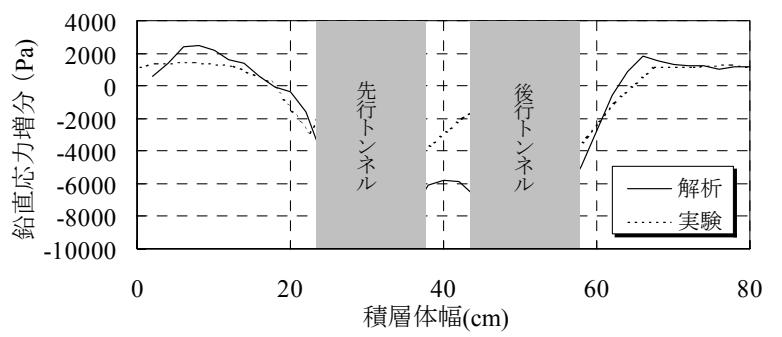

(c) 後行トンネル掘削 (Step1～Step3)

図-20 底盤土圧（緩夕厚 $0.01 \mathrm{D} ・$ 離隔0.3D）

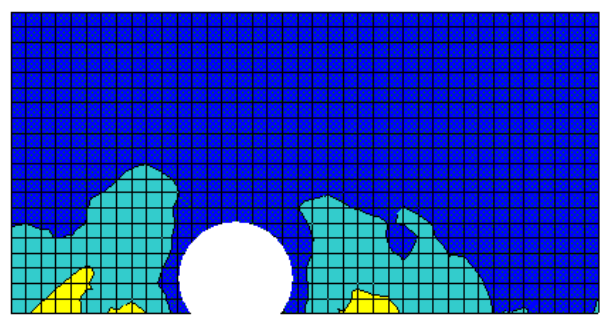

(a) 先行トンネル掘削 $($ Step1～Step2)

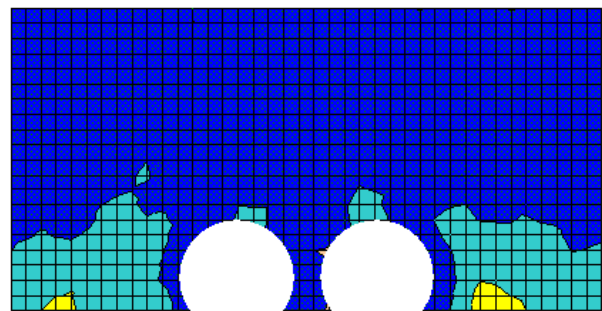

(b) 後行トンネル掘削 (Step1～Step3)

$\begin{array}{ccc}\text { 口 0-1000 } & \text { 口 1000-2000 } \\ \text { 口2000-3000 }\end{array}$

図-21 最大せん断応力等高線(単位 : Pa)

(緩夕厚 $0.01 \mathrm{D} ・$ 離隔 $0.3 \mathrm{D}$ )

行トンネル掘削後の結果であり, トンネル直上で $\lambda=1.1$ 〜1.5という結果となった。 これはTerzaghiの理論及び実 験2 による $\mathrm{K}_{0}=1.0 \sim 1.5$ とほぼ整合する結果となった。 た，トンネル側方底盤付近では $\lambda=0.4 \sim 0.5$ となりアー 


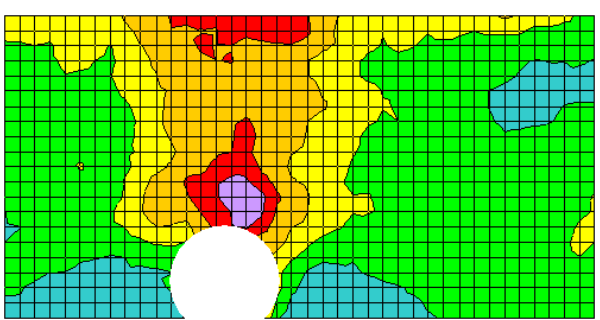

(a) 先行トンネル掘削 (Step1～Step2)

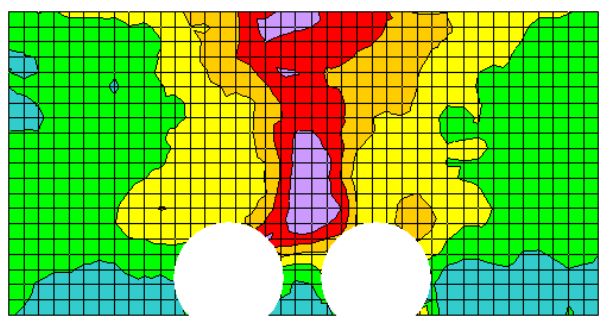

(b) 後行トンネル掘削 (Step1〜Step3)

\begin{tabular}{|llll|}
\hline$\square 0.0-0.2$ & $\square 0.2-0.4$ & $\square 0.4-0.6$ & $\square 0.6-0.8$ \\
$\square 0.8-1.0$ & $\square 1.0-1.2$ & $\square 1.2-1.4$ & $\square 1.4-1.6$ \\
\hline
\end{tabular}

図-22 側方土圧係数等高線（緩み厚 $0.01 \mathrm{D}$ ・離隔 $0.3 \mathrm{D}$ )

チング効果によりトンネル側方では鉛直応力が卓越し， トンネル上方では水平応力が卓越するという結果とな った. 図-22(b) は, 初期状態から後行トンネル掘削後 の結果であり，先行トンネルと後行トンネルの中央部 上方で $\lambda=1.4 \sim 1.6$ と大きな值となり, 先行及び後行卜 ンネル直上では $\lambda=0.8 \sim 1.1$ となった. また, 最大せん

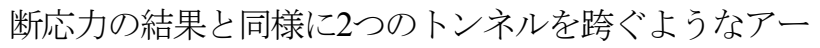
チング効果が見受けられる.

図-23に主応力ベクトルの分布図を示寸．図-23より， 図-24に示す最大主応力の流れの概念図のようにアーチ ング効果が生じていることが分かる.この頂部におけ る応力集中の現象は, 解析結果と実験結果の両者で現 われている. 寸なわち，トンネル模型全体を跨ぐアー チングの中にトンネル頂部を共通の脚とする2つのアー チングが生じていることが分かる.これは, 本研究で はトンネル法線方向に均一な緩みを与えており, 重力 場で粘着力の無い純粋な $\phi$ 材の地盤では, 図-24のよう に, トンネル頂部と側部(スプリングライン)近傍で地 盤粒子の下方への変位量が異なると考えられ，側部の 方が頂部よりも緩み度合が大きいことから，トンネル 頂部に向う応力の流れが生じていると考えられる.

\section{c） トンネル作用土圧}

図-25に, 解析結果と実験結果の各ステップの法線方 向周面作用土圧分布を示す. 図-25(a) は先行トンネル の結果である. 緩み量 $0.01 \mathrm{D}$ の本ケースでは, 先行トン ネル掘削時(単設時)にはTerzaghiの緩み土圧まで緩みき らないという結果となり, 後行トンネル掘削時(併設 時)は先行トンネル掘削時の作用土圧よりも増加した. その増加率はトンネル直上で, 解析で1.69倍, 実験で 1.51倍となり，1.5倍以上の増加率となった. 図-25(b) は

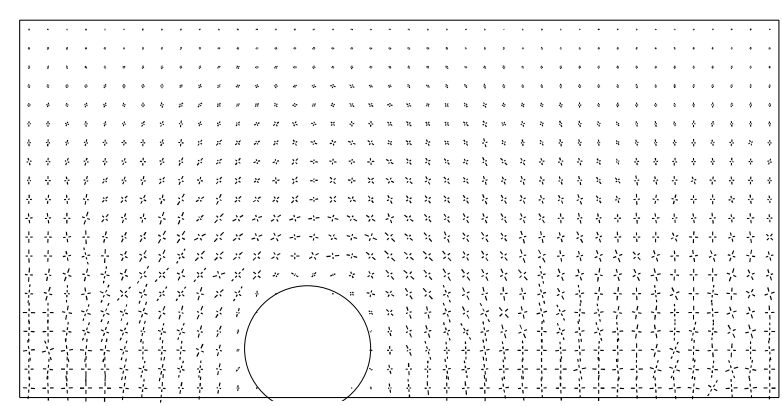

(a) 先行トンネル掘削 (Step1～Step2)

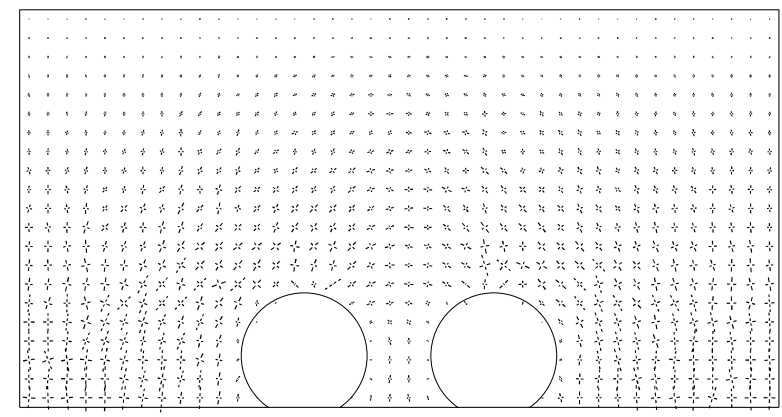

(b) 後行トンネル掘削 (Step1〜Step3)

図-23 主応力ベクトル（緩み厚0.01D・離融0.3D）

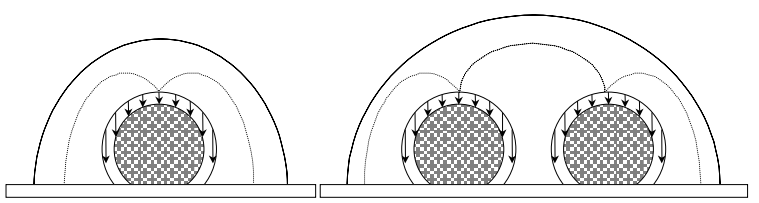

(a) 単設時

(b) 併設時

(破線 : 弱い流れ, 実線 : 強い流れ)

図-24 最大主応力流れ概念図

後行トンネルの結果であり, 図-25(a) と同様にTerzaghi の緩み土圧まで緩みきらないという結果となった。ま た, 先行トンネル掘削時(単設時)の先行トンネル作用 土圧より後行トンネル掘削時(併設時)の後行トンネル 作用土圧の方が大きな值となった。 これは, 先行トン ネル掘削により周辺地盤が緩んだ状態から後行トンネ ルを掘削したからであると考えられる.

\section{（6）緩み厚及び離隔を変えた時の解析結果}

\section{a）地盤変状}

図-26から図-31に先行トンネル掘削後から後行トン ネル掘削時 (Step2～Step3)の増分の最大せん断ひずみ等 高線の解析結果と実験結果を示す. 図-26から図-28は それぞれ緩み厚が0.001D，0.005D，0.01Dで離隔0.3Dの結 果であり，図-29から図-31はぞれぞれ離䛿が0.2D，0.3D， $0.5 \mathrm{D}$ で緩み厚が0.001Dの結果である.

図-26から図-28より，後行トンネル掘削時は，先行 トンネル掘削により一度トンネル周辺地盤が緩んでい る影響もあり，緩み厚 $0.001 \mathrm{D}(0.15 \mathrm{~mm})$ でもひずみ発生 


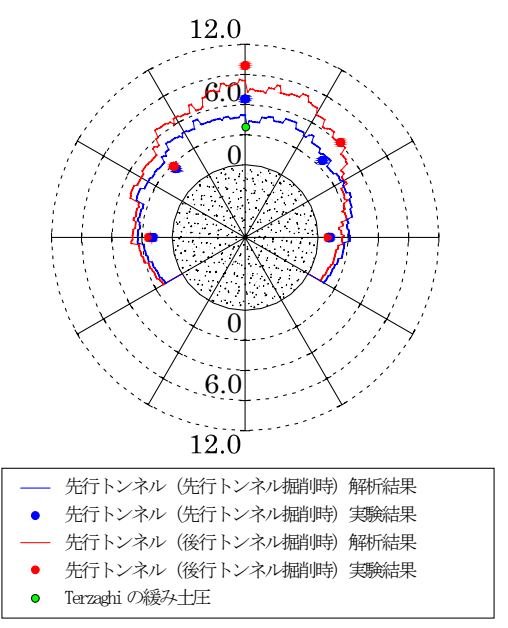

(a) 先行トンネル

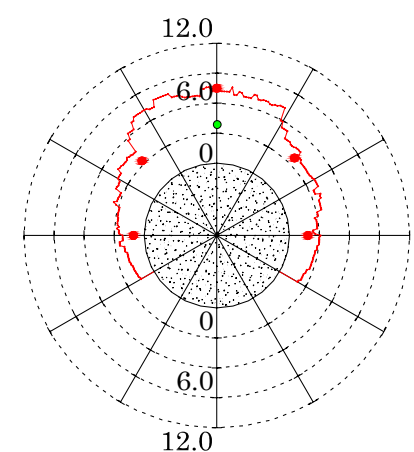

— 後行トンネル (後行トンネル掘削時) 解析結果
- 後行トンネル (後行トンネル掘削時) 実験結果 - Terzaghi の緩子土圧

図-25 トンネル法線方向周面作用土压(単位 : $\mathrm{kPa}$ ）（緩み厚 $0.01 \mathrm{D} ・$ 離隔 $0.3 \mathrm{D}$ )

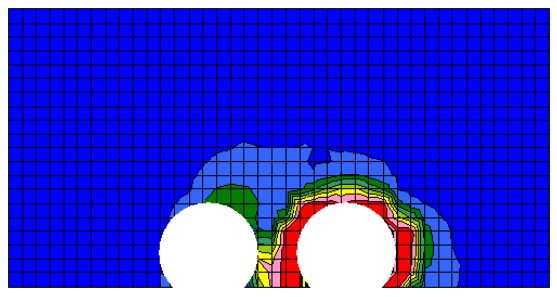

(a) 解析結果

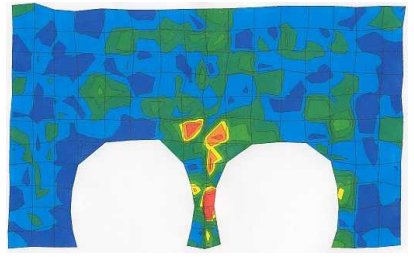

(b) 実験結果

図-26 緩み厚 $0.001 \mathrm{D} の$ 時の最大 せん断ひずみ等高線（離隔0.3D）

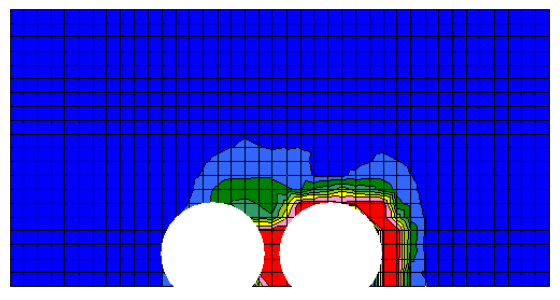

(a) 解析結果

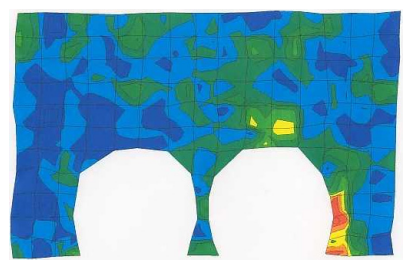

(b) 実験結果

図-29 離隔0.2Dの時の最大 せん断ひずみ等高線 (緩み厚 $0.001 \mathrm{D}$ )

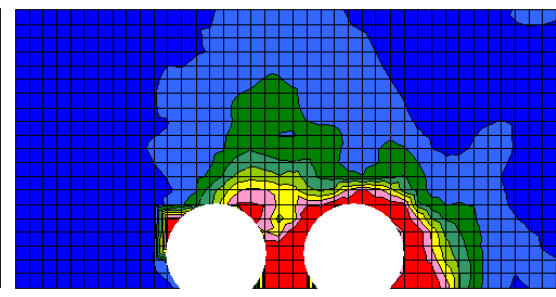

(a) 解析結果

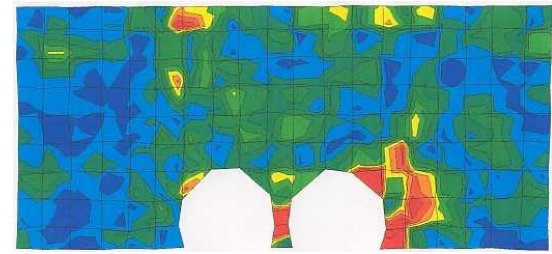

(b) 実験結果

図-27 緩み厚 $0.005 \mathrm{D} の$ 時の最大

せん断ひずみ等高線（離隔0.3D）

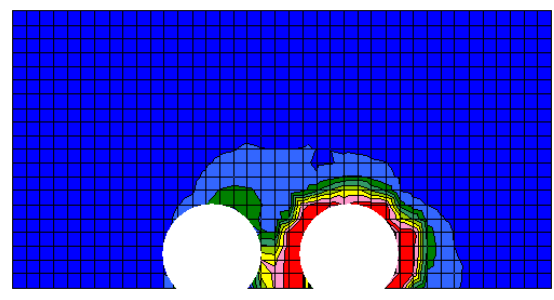

(a) 解析結果

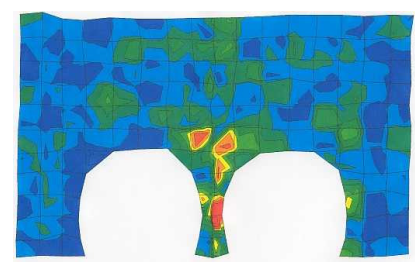

(b) 実験結果

図-30 離隔0.3Dの時の最大 せん断ひずみ等高線 (緩夕厚 $0.001 \mathrm{D}$ )

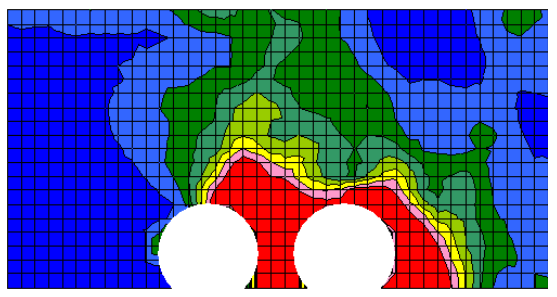

(a) 解析結果

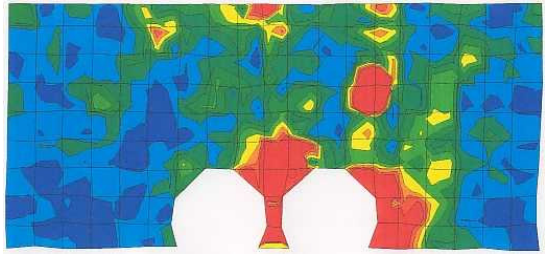

(b) 実験結果

図-28 緩み厚0.01Dの時の最大

せん断ひずみ等高線（離隔0.3D）

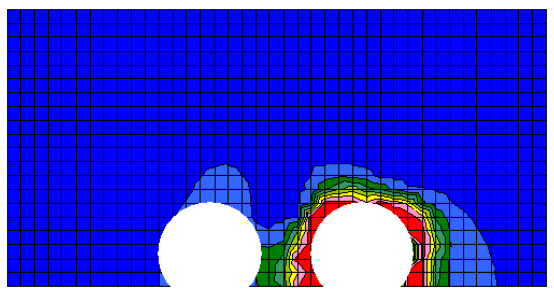

(a) 解析結果

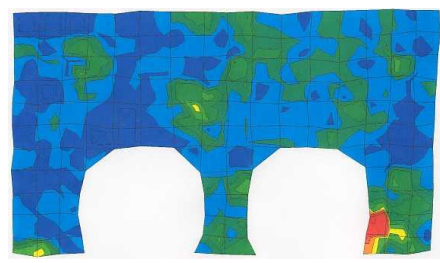

(b) 実験結果

図-31 離隔0.5Dの時の最大 せん断ひずみ等高線 (緩み厚 $0.001 \mathrm{D})$ 


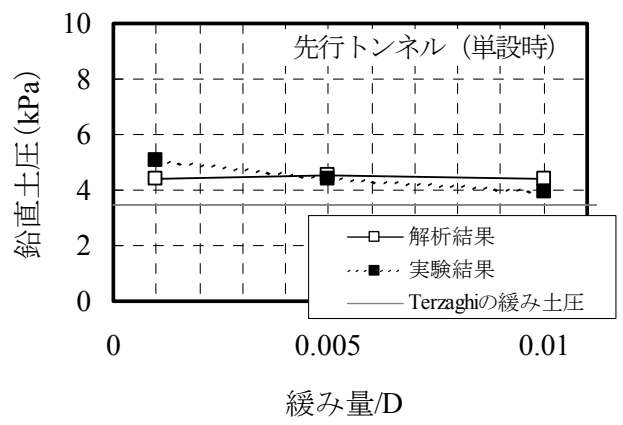

図-32 トンネル全体に作用する鉛直土圧 先行トンネル掘削 (Step1～Step2) (緩み厚の影響, 実験 : 離隔0.3D)

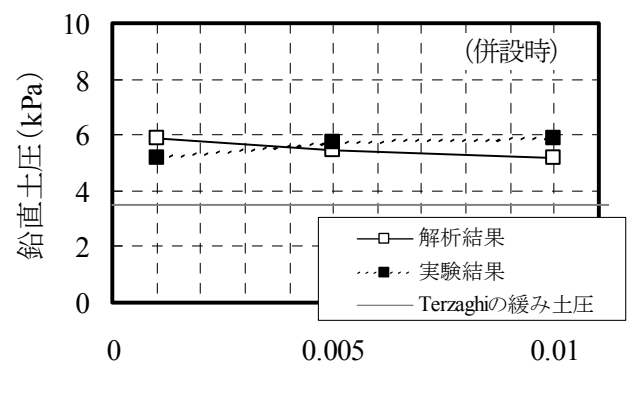

緩み量/D

(a) 先行トンネル

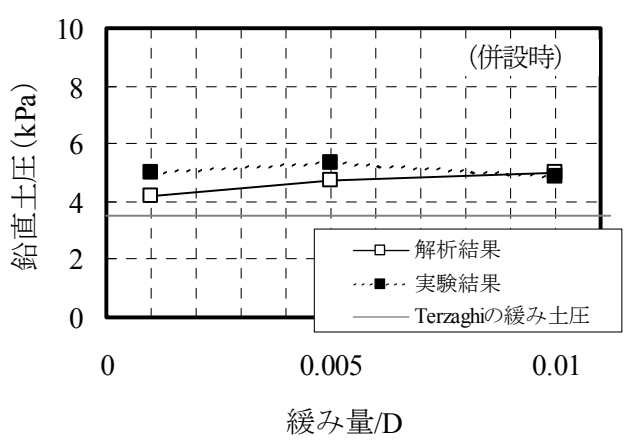

(b) 後行トンネル

図-33 トンネル全体に作用する鉛直土圧 後行トンネル掘削 (Step1～Step3) (離隔0.3Dのときの緩み厚の影響)

領域が先行トンネル周辺まで及んでいる。 また，先行 トンネルと後行トンネルの近接箇所とその上部の領域 に大きなひずみ(約0.02 (2.0\%))が生じる傾向となってお り, 緩み厚が大きいほど顕著である. 図-26から図-28 の (a) 解析結果と (b) 実験結果でひずみ発生領域と絶対 值は良く一致している.

図-29から図-31より，ひずみ発生領域は，離隔0.2Dで はトンネル近接箇所とその上部にまで及んでいるが, 離隔0.5Dでは後行トンネル周辺に集中している. した がって, 離隔が小さいほど, 後行トンネルを掘削する ことにより，先行トンネルに及ぼす影響が大きくなる ことが読取れる.

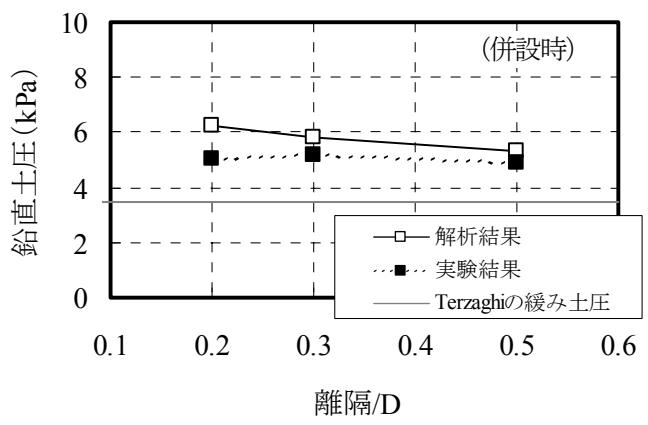

(a) 先行トンネル

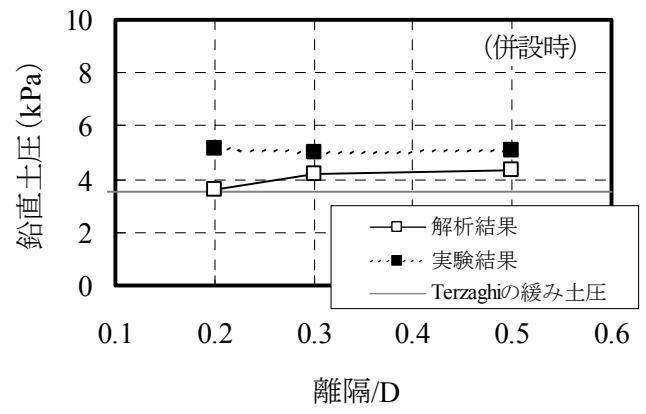

(b) 後行トンネル

図-34 トンネル全体に作用する鉛直土圧 後行トンネル掘削 (Step1～Step3) (緩み厚0.001Dのときの離隔の影響)

\section{b） トンネル作用土圧}

図-32，図-33及び図-34は，それぞれ，先行トンネル 掘削時(単設時)の緩み厚の影響, 離隔0.3Dで後行トン ネル掘削時(併設時)の緩み厚の影響, 緩み厚 $0.001 D$ で後 行トンネル掘削時(併設時)の離隔の影響に関してトン ネル全体に作用する鉛直全土圧を示したものである. これらより，緩み厚及び離隔の異なる全てのケースに おいて，先行トンネルに作用する鉛直全土圧は，後行 トンネルを掘削することにより, 応力の再配分の影響 で，増加していることが分かる(図-32と図-33(a) 及び 図-34(a)の比較)。また，先行トンネル及び後行トンネ ルは，実験と解析共にTerzaghiの緩み土圧まで緩みきら ない結果となった。

\section{4. 実験及び解析と現場計測とのトンネル挙動の 比較}

本章においては，実験及び解析により得られた併設 時の先行トンネルの挙動と現場計測結果とを定性的に 比較検討寸る.

現場計測結果は, 首都高速中央環状新宿線西新宿シ ールド工事のデータ1)を用いる. 計測断面の土質構成及 び設計条件を図-35に，現場計測結果を図-36及び図-37 に示す. 


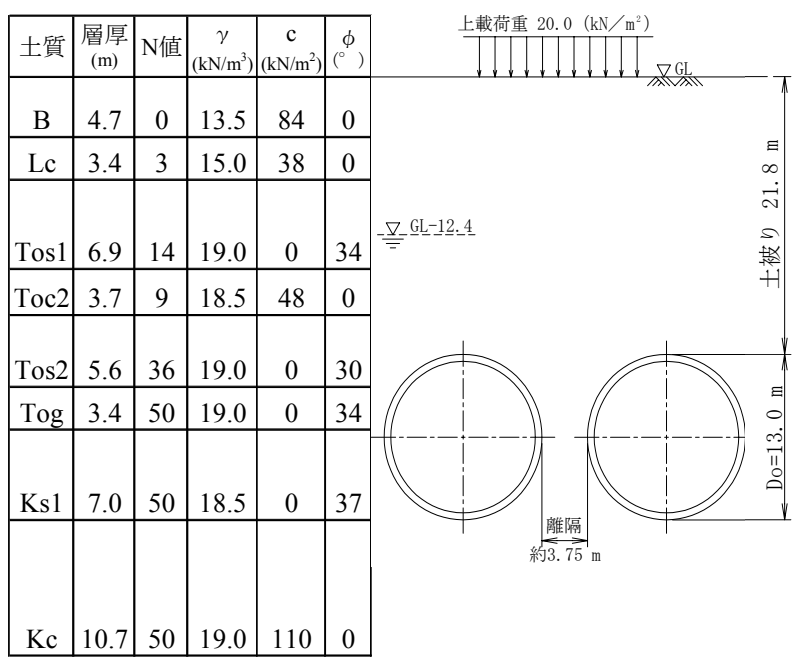

図-35 現場計測断面の土質構成及び設計条件

図-35に示寸計測断面は，土被りが約1.7D，離隔が約 0.3Dであり, 土質構成は, 表層に埋土層, ローム質粘 土層が存在し，東京層の粘性土が東京層の砂質土に挟 まれて存在しているが，トンネル施工位置及び直上か ら緩み領域に推定される位置では内部摩擦角が約 30(deg)またはそれ以上である砂質土が支配的であると 考えられる。一方，実験及び解析では，土被りが2D, 内部摩擦角が30(deg)のモデルであり, 離隔が0.3Dのケー スは概ね比較検討が可能であると判断できる.

図-36及び図-37の計測結果は，単設時から併設時の 先行トンネルに作用寸る有効土圧の増分比を時系列で 示したものである. 土水圧計の設置位置は, 図-36の卜 ンネル頂部(図中2) とスプリングライン左右(図中1及び 3) 及び，図-37のトンネル底部であり，水圧計は図-37の トンネル底部である。ここで，土水圧計計測值は，水 圧を含んだ值となっているため, 有効土圧を求めるに は土水圧計計測值から水圧分を減じる必要があるが, 土水圧計と水圧計の設置位置は同位置でないため, 水 圧計の計測值を水頭差に応じて換算し, 土水圧から水 圧を減じて, 有効土圧を算出した。 また, 図-36の計測 位置は, 実験及び解析におけるトンネル直上及び左右 $90^{\circ}$ の土圧計位置に作用する土圧と解釈でき，図-36の 計測位置は先行トンネルの底部であり, 計測結果は底 部地盤反力と解釈でき, 実験及び解析におけるトンネ ル全体に作用する鉛直全土圧と等価なものであると考 えられる。

図-36の計測結果より，併設安定時における単設安定 時からの有効土圧の増加率は, トンネル頂部(図中2)に おいて1.55倍，スプリングライン右側(図中1)で1.75倍, 左側(図中3)で1.10倍となり，トンネル頂部及びスプリ ングライン右側の増加率が大きい值となった．また， スプリングラインでは, 左側は併設の影響が少ない結 果となり, 右側は土圧が増加したが後行トンネル施工

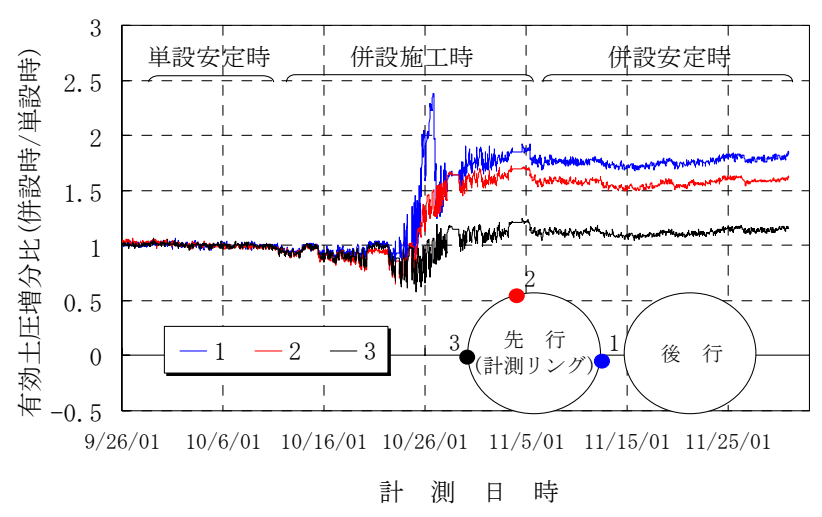

図-36 現場計測結果(有効土圧)

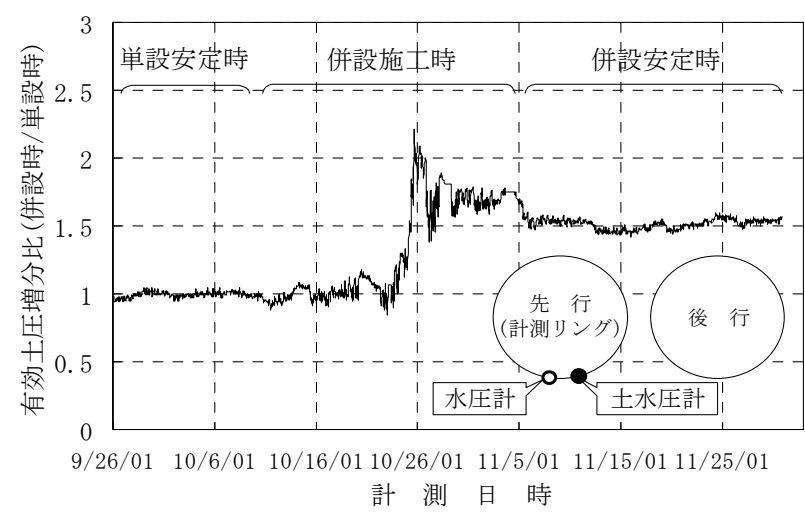

図-37 現場計測結果(有効土圧)

時のマシン掘削や裏込め注入の影響により近接部の地 盤が乱されて長期的影響として含んでいる，一方，実 験及び解析においても，図-25(a)より，トンネル頂部 付近において土圧は増加しており, 現場計測結果と比 較すると，トンネル頂部付近の増加率が最も大きい. 実験におけるトンネルモデルはセグメントの変形を伴 わない掘削による影響のみを捉えていることを勘案す れば，現象的に整合する結果となった。一方，実験及 び解析においては，マシン掘削や裏込め注入のないテ 一ルボイドの発生による緩みを表現しているため, ス プリングラインでは左右共に土圧は殆んど増加してい ない結果となっていることから，トンネル近接部のス プリングラインでは施工時の影響による長期的な土圧 増加の影響が大きいことが分かる。

図-37の計測結果より，併設安定時における単設安定 時からの有効土圧の増加率は約1.50倍となり, 後行トン ネルの掘削の影響により先行トンネルの土圧が増加し ていることが分かる，一方，実験及び解析においても， 図-32及び図-33(a)より，増加率は実験で1.49倍 (離隔 $0.3 \mathrm{D}$, 緩夕厚0.01Dのとき), 解析で1.33倍(離隔0.3D, 緩 み厚0.001Dのとき) となり, 現場計測結果と同様に後行 トンネルを掘削することにより先行トンネルの土圧は 増加している.

実験及び解析の模擬地盤と比較対象とした実施工の 
原地盤は厳密に一致していないが，後行トンネルを施 工することで応力再配分の影響により, 先行トンネル に土圧増加をもたらすことは, 現象的に概ね整合する 結果となった.

\section{5. 結論}

本研究は, 併設シールドトンネルの掘削に伴う周辺 地盤の緩み現象のメカニズムを把握することを目的と し, 模型実験とシミュレーション解析を行った. 模型

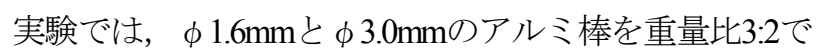
混合したアルミ棒積層体を模擬地盤とし，2つのトンネ ル模型周面に均一な緩みを与えた. シミュレーション 解析では, DEMを用いて模擬地盤及びトンネル模型を 1:1のスケールでモデル化し, 実験を再現した.

また，首都高速中央環状新宿線西新宿シールド工事 の現場計測結果を用いて実験及び解析による併設トン ネルの施工による先行トンネルの土圧変化の挙動を比 較検討した.

以下に，本研究により得られた知見を要約する.

（1）模型実験において，先行トンネル掘削時には，緩 み厚が大きいほど緩み土圧の影響により作用土圧は減 少し, 併設時(後行トンネル掘削時)には, 後行トンネ 儿掘削の影響を受け, 緩み厚が大きいほど応力再配分 の影響が顕著に現われ，作用土圧が増加した。

（2）模型実験において，トンネルを掘削するとき，周 辺地盤が緩んでいる状態の方が, 緩んでいない状態の ときよりも，土圧増加率が大きくなることが分かった． （3）DEM解析において，仮想地盤の内部摩擦角をアル ミ棒積層体の内部摩擦角と等しい值に設定し, 粒子の 回転を制限するなどにより, 実験結果を概ねシミュレ 一ト可能であり, 地盤の変位や応力, トンネル作用土 圧の定量的な評価が可能であることが分かった。

（4）先行トンネル掘削時には, 地表面沈下及び地盤内 沈下共にほぼトンネル直上で最大沈下が生じ，併設時 (後行トンネル掘削時)には, 先行トンネルと後行トン ネルの近接中間部の上方で最大沈下が生じた.

（5）地盤内せん断ひずみ分布より，緩み厚が小さいと き(0.001D) はトンネル周辺にひずみが生じているのに対 し, 緩み厚が大きいとき (0.01D) は重力場の影響が大き く現われており, トンネル周辺から積層体上部に渡り ひずみが生じる結果となった．また，離隔が狭いほど トンネル近接部において大きなひずみが生じ，併設の 影響が大きくなった.

（6）地盤内変位及び応力より, 先行トンネル掘削時の 周辺地盤の緩みにより形成されたアーチが後行トンネ
ルを掘削することにより，2つのトンネルを跨ぐような アーチに再形成されることを確認した.

（7）解析結果より, 側方土圧係数は, 先行トンネル掘 削時にはトンネル直上で $\lambda=1.1 \sim 1.5$ となり, Terzaghiの 理論及び実験1による結果とほぼ整合する結果となった。 併設時にはトンネル近接箇所上方において $\lambda=1.4 \sim 1.6$ と大きな值となり，2つのトンネルを跨ぐようなアーチ ング効果が見受けらた。

（8）重力場において粘着力の無い純粋な $\phi$ 材の地盤で は, トンネル法線方向に均一な緩みを与えると，トン ネル頂部とスプリングライン付近では地盤粒子の下方 への変位量が異なると考えられ，トンネル頂部に向か う応力の流れが生じることが分かった。

（9）実験及び解析の結果より, 緩み厚及び離隔の異な る全てのケースにおいて，先行トンネルに作用する鉛 直全土圧は，併設時には応力再配分の影響により増加 した，その増加率は最大で1.5倍程度であった．また， 全てのケースにおいて，Terzaghiの緩み土圧まで緩みき らない結果となった.

（10）実験及び解析の結果と現場計測結果を比較したと ころ，共に後行トンネルを掘削することにより先行ト ンネルの作用土圧は増加し, その増加率はトンネル頂 部で最も大きくなり, 現象的に概ね整合する結果とな った.

謝辞：多忙な中, 数值解析について, 貴重な助言と指 導を頂きました（株）竹中工務店竹中技術研究所・塩 見忠彦氏，恒川祐史氏に感謝の意を表します。

\section{参考文献}

1）田嶋仁志, 岸田政彦, 川田成彦, 小林靖典, 斉藤正幸 : 併設シールドトンネルの影響評価方法に関する検討, トン ネル工学研究論文・報告集, 第13巻, pp.407-412,2003.

2) Terzaghi, K.: Theoretical Soil Mechanics, Chapman and Hall Limited, John Wiley and Sons, INC, New York, 1959.

3）土木学会編, トンネル標準示方書[シールド工法編 $]$ ・同解 説, 1996.

4）鉄道総合技術研究所編，鉄道構造物等設計標準・同解説 シ ールドトンネル, 1997.

5）村山朔朗 : 砂層内局部沈下部にかかる鉛直土圧, 京都大学 防災研究所年報, No.11B,pp. 123-138, 1968.

6）村山朔朗，松岡 元 : 砂質土中のトンネル土圧に関する基 礎的研究，土木学会論文集，No.187,pp.95-108, 1971.

7）足立紀尚, 田村 武, 八嶋 厚, 上野 洋: 砂質地山トン ネルの挙動と解析に関する研究, 土木学会論文集, No.358/III-3,pp. 129-136, 1985.

8）芥川真一，吉田 千，得能達生 : 応力制御型トンネル掘削 
シミュレーション実験装置の改良と検証, 土木学会第56回 年次学術講演会, Vol.56-III-B030, pp.60-61,2001.

9）足立紀尚, 木村 亮, 岸田 潔, 伊藤浩志: 降下床実験に よるトンネル掘削過程を考慮したトンネルおよび周辺地盤 の力学挙動の解明, 土木学会論文集, No.694/III-57, pp. 277$296,2001$.

10）今田 徹, 元山 宏, 三木克彦, 金井 誠: シールドト ンネル覆工荷重に与えるゆるみの影響に関する研究, 土木 学会論文集, No.439/III-17,pp. 79-88, 1991.

11）小山幸則, 清水 満, 佐藤 豊: トンネルに作用する土 圧の研究(1), 土木学会第48回年次学術講演会, Vol.48-III-51, pp. 156-157, 1993.

12）垂水尚志, 山本征彦, 野口利雄 : 落し戸降下後の表面載 荷に伴う荷重分布, トンネル工学研究論文・報告集, 第3 卷, pp. 27-34, 1993.

13）鈴木正彦, 真下英人, 山本雅広 : 併設される複数のシー ルドに作用する荷重に関する基礎的研究，トンネル工学研 究発表会論文・報告集，第7巻，pp. 331-336, 1997.

14）土門 剛, 西村和夫, 今田 徹, 藤井義文, 小笠原政 文: 多連接小断面トンネル掘削を模擬した3連降下床実験, 土木学会第53回年次学術講演会, Vol.53-III-B194, pp. 388-389, 1998.

15）桜井春輔, 丸岡 巧, チャールズ・アカユリ, 芥川真 一: 双設トンネルの挙動と中壁部に作用する土圧に関する 研究, トンネル工学研究発表会論文・報告集, 第6巻, pp. 83-88, 1996.

16）小坂寛巳, 今田 徹, 小笠原政文, 津野和宏, 藤井義文, 平井 卓: 水平に近接した 2 本の円形セグメントに作用す るゆるみ土圧，土木学会論文集，No.596/III-43,pp. 65-79, 1998.

17）高野晴夫, 今田 徹, 小笠原政文, 舩本浩二, 藤井義文, 平井 卓 : 併設横長矩形シールドトンネルの作用土圧に関 する遠心載荷実験, 土木学会論文集, No.638/III-49, pp. 167$178,1999$.

18）小野顕司, 清水一郎, 西田義則, 趈田貴志: 離隔 $30 \mathrm{~cm}$ 以 下の併設泥土圧シールドっくばエクスプレスつくばトンネ ル，トンネルと地下，Vol.35,No.2,2004.
19）土門 剛, 丹沢淳一, 西村和夫 : トンネル下部まで根入 れした垂直縫地ボルトの補強効果, 土木学会第57回年次学 術講演会, Vol.57-III-256, pp.511-512,2002.

20) Cundall, P. A. : A computer model for simulating progressive, large scale movements in blocky rock systems., Proc. Symp. Int. Rock Mech., Vol.2, pp.129-136, Nancy, Oct 1971.

21) Cundall, P. A. : Explicit finite differnce method in geomechanics, Second Int. Conf. Numerical Methods in Geomechanics., Vol.1, pp.132-150, Blacksburg, 1976.

22) Cundall, P. A. : A discrete numerical model for granular assemblies, Geotechnique, Vol.29, No.1,pp.47-65, 1979.

23）木山英郎：岩質粒状体の重力流動に関する基礎研究, 土 木学会論文集, No.322,pp. 101-110, 1982.

24）中田雅博, 中野清人, 西村和夫, 森田 篤, 松井幹夫, 進士正人 : 落し戸実験の数值解析法としてのDEMの適用性 と問題点について, 土木学会第49回年次学術講演会, Vol.49-III-564, pp.1118-1119, 1994.

25) 木山英郎, 藤村 尚, 西村 強, 吉田尚起 : トンネル掘 削時の周辺地盤の個別要素法解析, 土木学会第52回年次学 術講演会, Vol.52-III-B79, pp. 158-159, 1997.

26）小笠原政文, 津野和宏, 舩本浩二, 藤井義文, 平井 卓, 野村茂樹 : 個別要素法を用いた併設矩形シールドの作用土 圧に関する検討, 第33回地盤工学研究発表会, pp. 1945-1946, 1998.

27）木山英郎, 藤村 尚 : カンドルの離散剛要素法を用いた 岩質粒状体の重力流動の解析, 土木学会論文集, No.333, pp. 137-146, 1983.

28）岩下和義, 松浦浩一, 小田匡寛 : 粒子節点でのモーメン 卜伝達を考慮した個別要素法の研究, 土木学会論文集, No.529/III-33, pp. 145-154, 1995.

29）岩下和義, 小田匡寛 : 粒子節点での転がり抵抗を考慮し た個別要素法によるせん断帯の微視的変形機構, 土木学会 応用力学論文集, Vol.2,pp.401-411, 1999.

(2005.5.11 受付) 


\section{THE LOOSING PHENOMENON IN THE SAND GROUND BY EXCAVATION OF CLOSE PARALLEL SHIELD TUNNELS}

\section{Hitoshi TAJIMA, Takahiro ISHIDA, Masayuki SAITOH, Yasunori KOBAYASHI, Yasuhiro NAKANISHI, Akio ICHIKAWA and Kazuo NISHIMURA}

This research is to clarify the mechanism of the loosing phenomenon of the surrounding ground as a longterm influence by the excavation of the close parallel shield tunnels. The research examined the effect of loosing quantity by the occurrence of tail-void and the effect of distance of the parallel tunnels. The model experiment was conducted, in which aluminum rod mass using two tunnel models was applied as a simulated ground, and the simulation analysis by distinct element method (DEM) analysis was done. As a result, the soil pressure that was on the first tunnel increased by the influence of excavation of the second tunnel, and the ground arching effect which strides over two tunnels was confirmed. Moreover, the results of analysis and experiment were also compared with measuring results in the construction. 